\title{
ASPECTOS DA CULTURA DO JARDIM E DO DESENVOLVIMENTO DOS ESPAÇOS LIVRES NA ALEMANHA
}

\author{
Aspects of garden culture and open space development in Germany
}

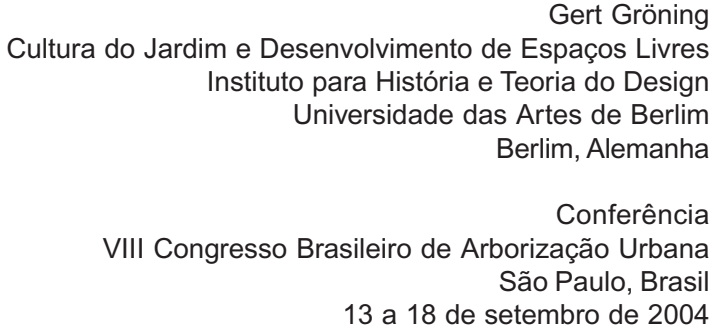

Tradução do original em inglês/alemão: Arq. Msc. Paulo Celso Dornelles Del Picchia

\section{SAUDAÇÕES}

Prezado Coordenador da Comissão Organizadora. Prezados companheiros pesquisadores. Prezados estudantes. Senhoras e Senhores:

Muito me agrada a oportunidade de vir a São Paulo para apresentar algumas das minhas idéias e de aprender com as apresentações e discussões por ocasião do VIII Congresso Brasileiro de Arborização Urbana. Grato a todos. Isto me faz sentir bem.

Dedico esta conferência a Felisberto Cavalheiro (1945-2003) ${ }^{1}$ que faleceu no ano passado, muito cedo, como professor do Departamento de Geografia da Universidade de São Paulo. Ele foi um dos mais ativos entusiastas dos espaços livres no Brasil como muitos dos senhores sabem melhor do que eu. Agrada-me especialmente que a Sociedade Brasileira de Arborização Urbana tenha decidido manter sua memória no seu site da Internet.

\section{ALGUMAS CONSIDERAÇÕES SOBRE AABORDAGEM REDUCIONISTA DA ECOLOGIA E AS PRIMEIRAS EX- PERIÊNCIAS DE ARBORIZAÇÃO NA ALEMANHA}

Muitas publicações do passado - século XX e começo do século XXI - popularizaram uma maneira biológica de ver o mundo. O século XX viu a introdução do que se chamou então biosfera.

Característica de tal visão é que os seres humanos e suas dimensões espirituais, intelectuais e sociais não são partes desse pensamento que freqüentemente é chamado "ecológico". Não é de se surpreender então ao ver representações de uma cidade que se intitula "ecológica" e que, ao mesmo tempo, omite quase completamente a diversidade de relações humanas e realizações em uma cidade. Nos séculos XIX, XX e início do século $\mathrm{XXI}$, alguns ecologistas viram as grandes cidades como elementos destrutivos do que eles consideram natureza ${ }^{2}$ (Figura 1). Se aceitável, então, para eles as grandes ci-

${ }^{1} \mathrm{O}$ título de sua tese de doutorado foi "Die kommunale Freiraumverwaltung in São Paulo, Brasilien - Gegenwärtige Situation und Chancen zukünftiger Entwicklung" (Administração Municipal de Espaços Livres em São Paulo, Brasil - Situação atual e opções para futuro desenvolvimento). Foi aceita após uma argüição oral em 29 de junho de 1981 por uma comissão do programa de arquitetura paisagística da Universidade de Hannover, Alemanha.

2 Veja, por exemplo, a representação do ecossistema de uma cidade (Figura 1) in SUKOPP, Herbert 1973: Die Grosstadt als Gegenstand ökologischer Forschung, TUB, Zeitschrift der Technischen Universität Berlin, 5, 710-717. 
FIGURA 1 - ECOSSISTEMA DE UMA CIDADE (SUKOPP, 1973). UMA VISÃO "ECOLÓGICA" DA CIDADE GRANDE; MUDANÇAS NO QUE É CHAMADA "BIOSFERA" DE UMA CIDADE GRANDE; POLUIÇÃO ATMOSFÉRICA, AQUECIMENTO DO AR; REDUZIDA UMIDADE DO AR, REDUZIDAS TROCAS AÉREAS, ÁGUAS EUTROFIZADAS, REBAIXAMENTO DOS LENÇÓIS FREÁTICOS, CANALIZAÇÃO DE ÁGUAS, REDUÇÃO E DESTRUIÇÃO DE VEGETAÇÃO, ETC.

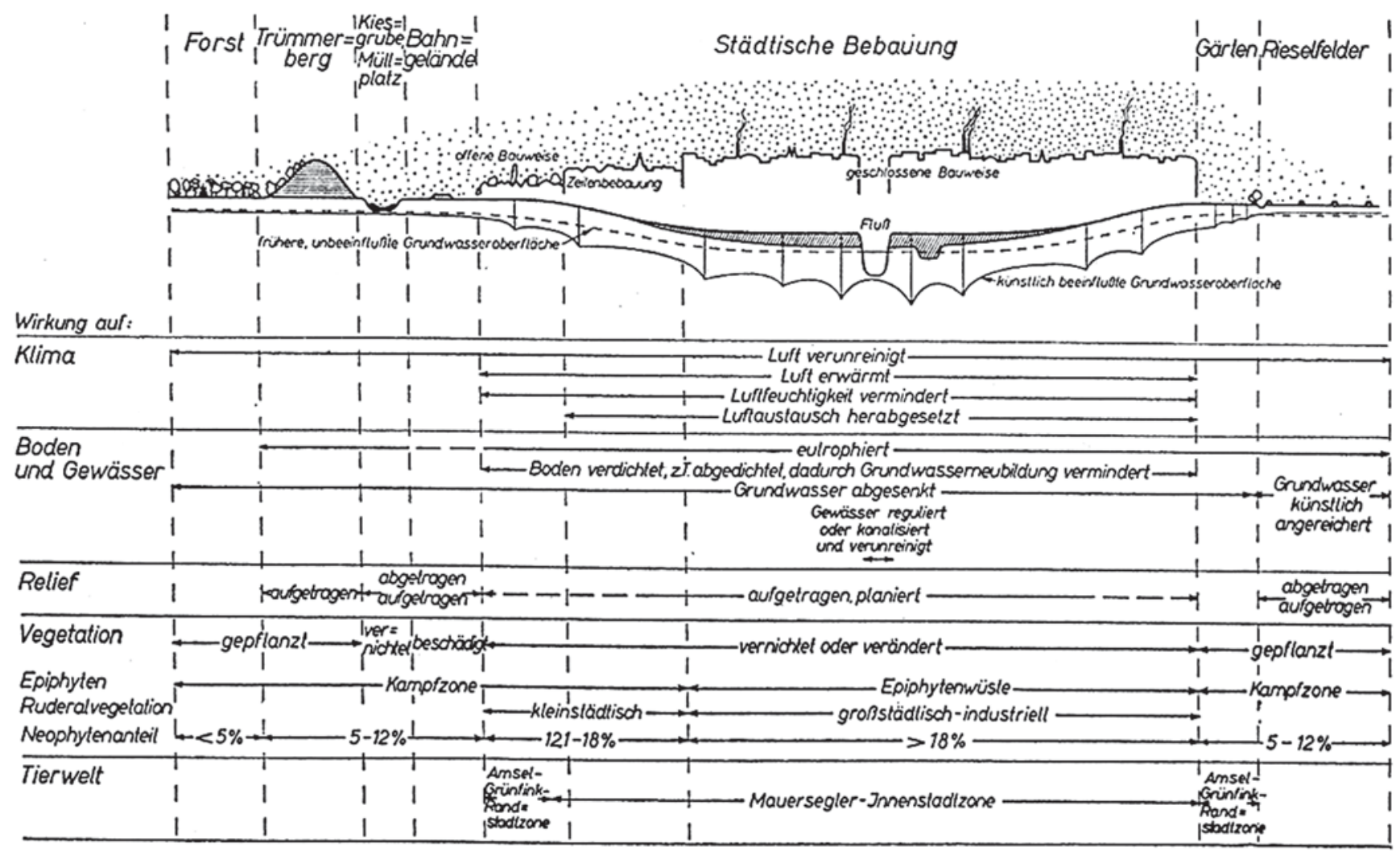

dades parecem, na melhor das hipóteses, "toleráveis". Parece que eles têm dificuldade de ver algumas forças construtivas nas grandes cidades. Esta visão é notável desde que passou a existir uma tendência mundial à urbanização.

Contra tais visões ecologistas, o povo, que é a força motora por trás dessa tendência, obviamente prefere as cidades em lugar dessas áreas "naturais, ecologicamente intactas" que eles abandonaram porque esperavam ou sabiam que poderiam ter uma melhor qualidade de vida nas cidades. O desprezo dos aspectos sociais, econômicos e políticos do desenvolvimento humano é um erro cardeal deste assim chamado ponto de vista ecológico. Esta visão "ecológica" tenta fazer crer que os incríveis processos complexos da civilização de muitas centenas de milhares de pessoas neste planeta são negligenciáveis. Como se a ecologia nada tivesse a ver com a civilização. Isto considero notável.
O quão importante é incluir as dimensões sociais, políticas e econômicas da civilização humana deve ser óbvio a todos que pensam em mudar a situação de mal para bom. Isto se refere também à arborização.

Tão cedo quanto 1821 Gustav Vorherr (1778-1847), um advogado da arborização do território das aldeias da Baviera teve que aprender que suas propostas não eram seguidas porque ele não considerou a visão de seus companheiros cidadãos sobre esse assunto ${ }^{3}$ (Figura 2).

Muitas cidades foram arborizadas no curso do século XIX. Por exemplo, a cidade de Mannheim produziu vários planos de arborização para suas ruas (Figura 3).

Outra significativa idéia precoce de arborização foi o estabelecimento de viveiros nacionais de árvores que deveriam servir a todos os cidadãos que o desejassem, árvores em condições muito favoráveis (Figura 4). Esta foi uma idéia a qual Peter Joseph Lenné (1789-1866), que muitos consideram o ancestral dos arquitetos paisa-

${ }^{3}$ Para maiores informações sobre as atividades de Vorherr veja GRÖNING, Gert 1992: The Idea of land embellishment. As exemplified in the Monatsblatt für Verbesserung dês Landbauwesens und für zweckmässige Verschönerung des baierischen Landes (Monthly for improvement of rural architecture and appropriate embellishment of the state of Bavaria), from 1821 to 1829, Journal of Garden History, 12, 3, 164-182. 
FIGURA 2 - A ALDEIA DE FREUDENBACH NA BAVIERA COMO ELA É [À ESQUERDA], E COMO VORHERR ESPERAVA QUE ELA SE TORNASSE [À DIREITA], 1821. VEJA A TENTATIVA DE VORHERR DE ARBORIZAR A ALDEIA NUMA MANEIRA RETANGULAR.
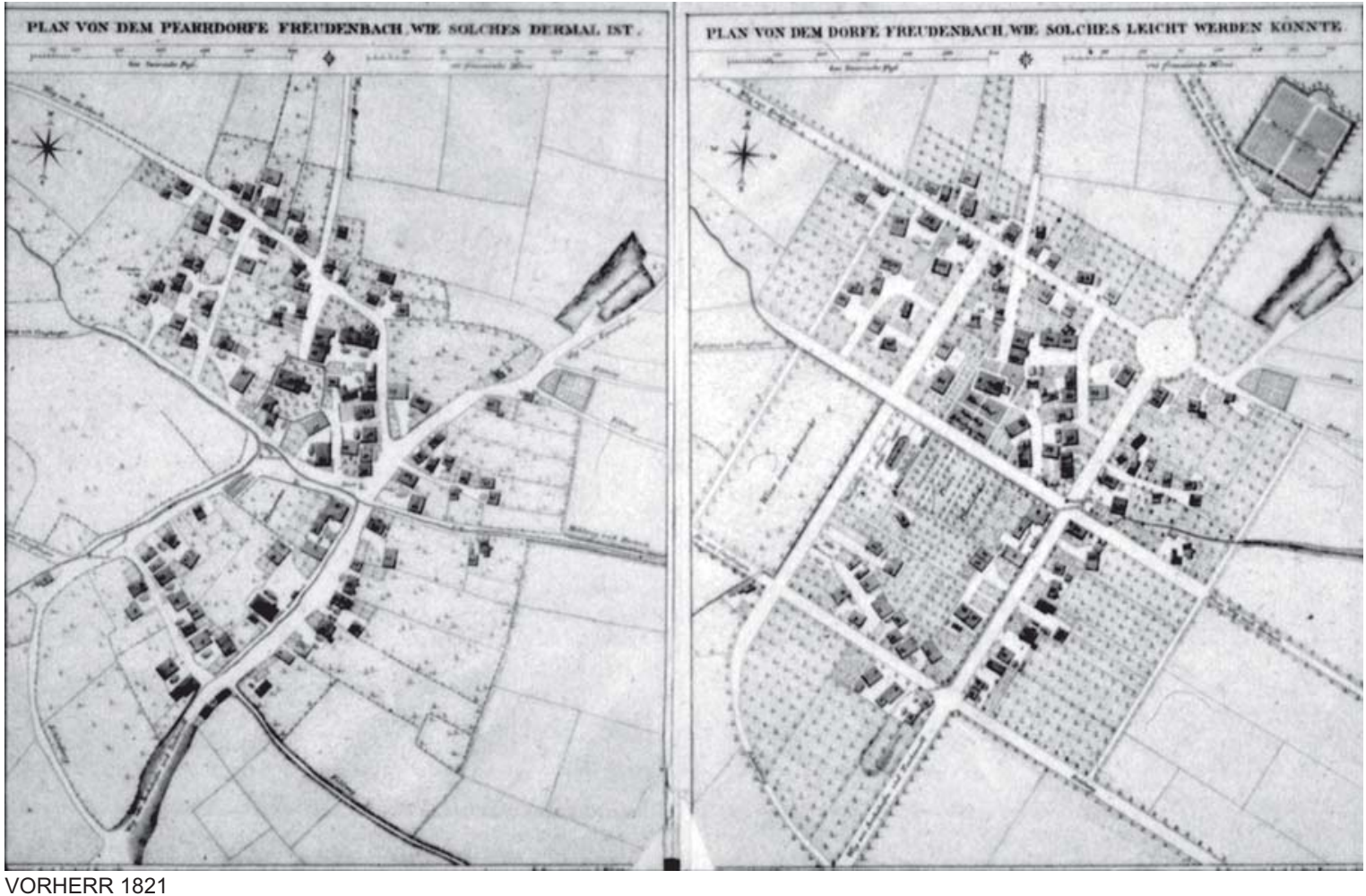

FIGURA 3 - MANHEIM, ARBORIZAÇÃO DE RUAS, SÉCULO XIX
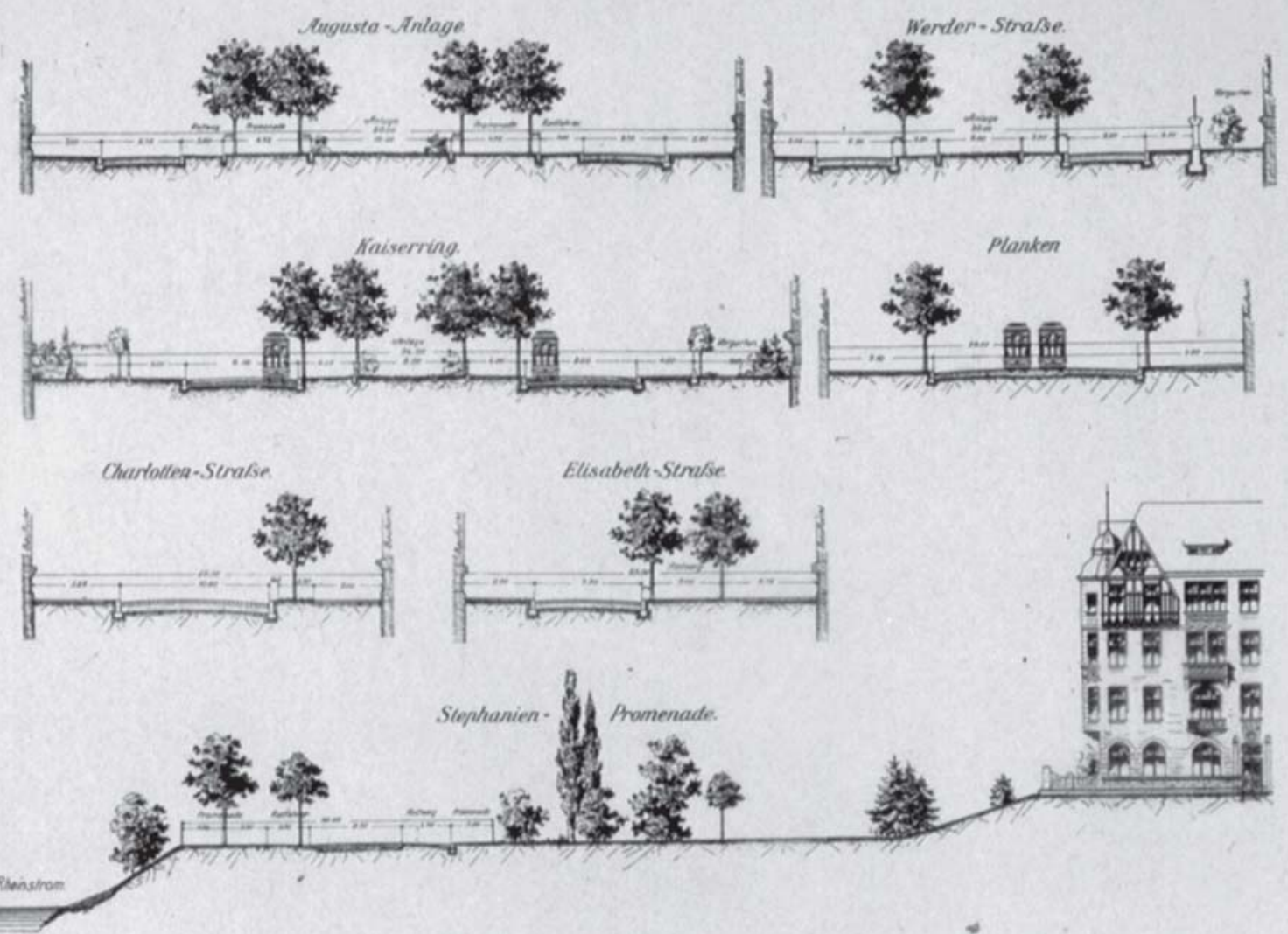
GRÖNING, G. Aspectos da cultura do jardim...

FIGURA 4 -VIVEIRO DE ÁRVORES PALACIANO (PINHEIROS), POTSDAM, PLANTA DE LOCALIZACCÃO. VIVEIRO DE ÁRVORES PALACIANO [PINHEIROS] A ABAIXO, ÁRVORES EM ESTADO NATURAL PARA O CRESCIMENTO DE CONÍFERAS, ETC.; B NOROESTE DE A, ESPAÇO PARA PLANTAS EM VASO; C ARREDORES A E B, DIVERSAS ÁRVORES DE QUALIDADE; E OESTE DE C, SEMENTEIRAS; F DO MEIO PARA OESTE, VIVEIRO DE ESTACAS; G DO CENTRO PARA OESTE, VIVEIROS DE ÁRVORES; H CENTRO NOROESTE, REPRODUCCÃO POR BROTAÇÕES; J ENTRE G E H, ARMAZENAMENTO DE SOLO; K NOROESTE, CANTEIRO DE VEGETAÇÃO; L CENTRO FAIXA VERDE AMARELA, CAMPINA.

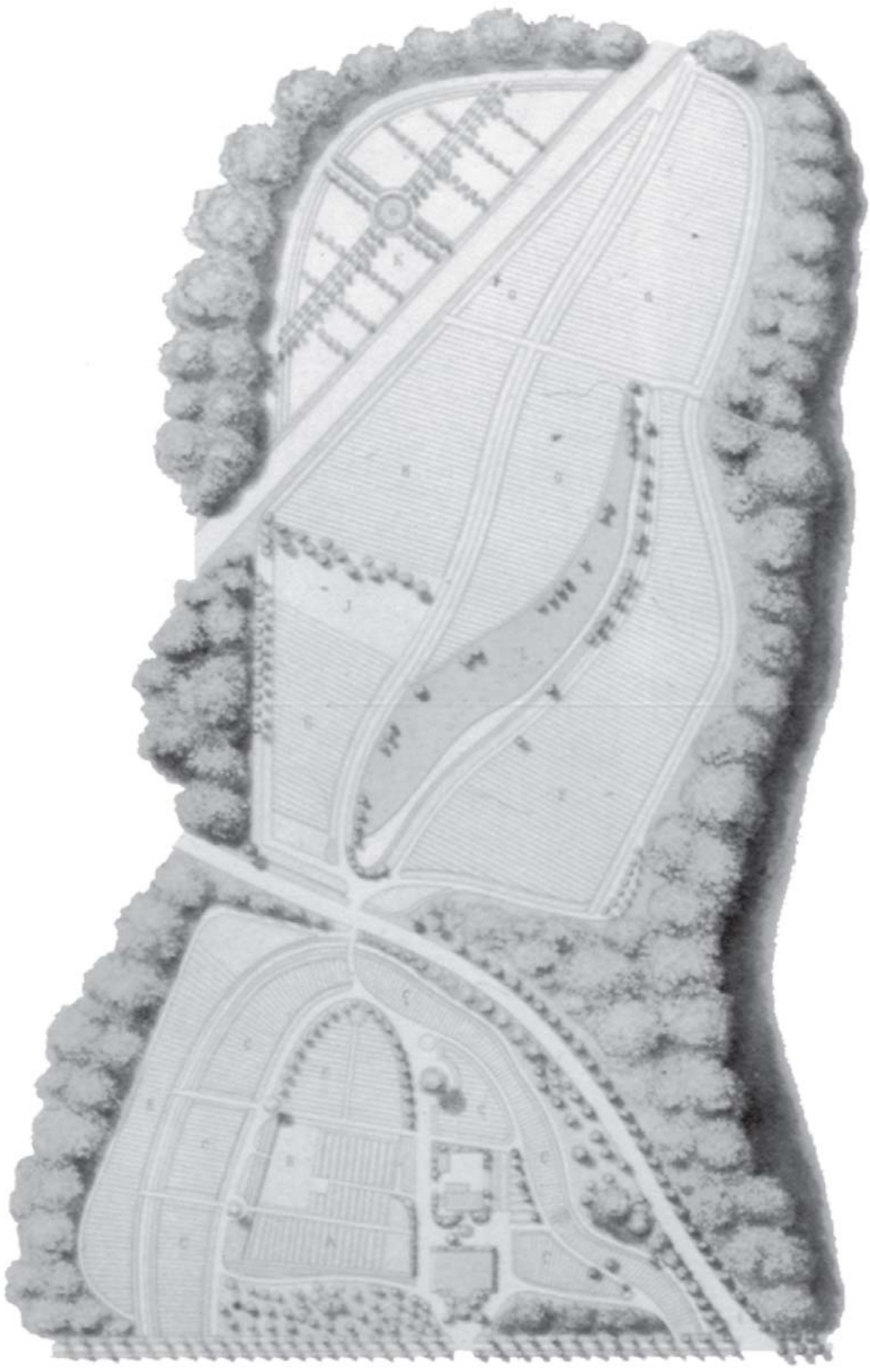


gistas na Alemanha, sugeriu no começo do século XIX e que começou a ser implementada com o estabelecimento de um viveiro nacional de árvores e de uma escola para o treinamento de jardineiros em 1823 na Prússia e a magnífica edição de um jornal, o "Tratado da Associação para a promoção da Horticultura nos estados reais da Prússia" (Verhandlungen des Vereins zur Beförderung dês Gartenbaus in der königlich preussischen Saaten $)^{4}$

Outrora entendia-se que mudanças não poderiam ser efetuadas numa base individual, mas necessitavam de forças conjuntas, necessitavam de formação de coalizões, e muita atividade política, então, a necessidade de conhecimento sobre interesses humanos é clara.

\section{EM DIREÇÃO A UMA TEORIA DE ESPAÇOS LIVRES EM UM MUNDO URBANIZADO DO SÉCULO XXI}

Cada disciplina deve tentar estabelecer uma teoria se ela pretende encontrar uma estrutura para os resultados de vários esforços de pesquisa individuais. Esta é uma tarefa longe de ser fácil. Parece que na arquitetura paisagística das últimas décadas na Alemanha o termo "ecologia" serviu freqüentemente para disfarçar uma falta de teoria que poderia proporcionar localizar qualquer resultado "ecológico". Inúmeras outras disciplinas tais como medicina, musicologia, química, física, ${ }^{5}$ em literatura e na historia da arte, mostram mais racionalidade teórica que a arquitetura paisagística. Embora o planejamento da paisagem freqüentemente reclame ser a única disciplina com uma visão ecológica em oposição a todas as outras.
No que se refere a Alemanha isto é bizarro. Até recentemente havia um forte interesse no que se tem chamado "conservação do território" (Landespflege) pelos planejadores da paisagem Nacionais Socialistas. Algumas pessoas na Alemanha ainda têm dificuldades de se afastar de tais posições depois da libertação do Nacional Socialismo ${ }^{6}$ o que precisamente ocorreu há 60 anos (Figura 5).

Assim o planejamento da paisagem na Alemanha ainda não conseguiu claramente afastar-se de tais inclinações Nacionais Socialistas. Em 2002, uma conferência em Berlim sobre proteção à natureza e Nacional Socialismo não encontrou nada de errado entre proteção à natureza e Nacional Socialismo. ${ }^{7}$ Isto é notável na importância de que todos os mais graduados representantes da proteção à natureza estavam ativamente engajados em atividades nacionais socialistas e sustentaram idéias racistas e nacionalistas. ${ }^{8}$

O cientista social Norbert ELIAS (1897-1990) que estudou a fundo o processo de civilização desenvolveu uma significativa hipótese. Sua pesquisa revelou que no desenvolvimento da civilização nas sociedades européias a necessidade de verificar emoções, paixões e impulsividade tornou-se mais e mais significativa. ${ }^{9} \mathrm{Em}$ auxílio dessa hipótese penso que será mais e mais significativo para o desenvolvimento da civilização verificar democraticamente como diferentes grupos de uma sociedade se apropria e domina a natureza. Com tal estrutura de procedimento caminhos serão abertos em direção a uma teoria (do jardim) como parte do debate da cultura do jardim e do desenvolvimento dos espaços livres no mundo em urbanização do século XXI.

\footnotetext{
${ }^{4}$ Veja GRÖNING, Gert 1989: Peter Joseph Lenné und der "Verein zur Beförderung des Gartenbaues in den Königlich Preussischen Staaten" Buttlar, Florian von, im Auftrag der Senatsverwaltung für Stadtentwicklung und Umweltschutz (ed.), Peter Joseph Lenné, Volkspark und Arkadien, 82-90, Berlin.

${ }^{5}$ Veja por ex. MUTSCHLER, Hans Dieter 1993: Zwei Kulturen sind besser als keine, Wider die physikalistischen Ganzheitslehren, Merkur, 47, 11, 998-1003.

${ }^{6}$ Veja GRÖNING, Gert e Joachim WOLSCHKE-BUHLMAHN 2003: Zum Verhältnis von Landschaftsplanung und Nationalsozialismus, Stiftung Naturschutzgeschichte (ed.) Naturschutz hat Geschichte, Veröffentlichungen der Stiftung Naturschutzgeschichte, volume 4, 163191, Essen; veja GRÖNING, Gert 1999: Gartenkultur in Klein- und Hausgärten in historischen Wandel, Bundesverband de Diplomingenieure Gartenbau und Landespflege e.V. (Hg.), Beziehung, Mensch und Pflanze im Wandel der Gesellschaft - Garten, Park, Landschaft, BDGLSchriftenreihe, 7-24, Bonn; veja também GRÖNING, Gert 1998: Die Suche nach der „Landschaftsmitte”, Kursbuch, 131, 55-69, Berlim; veja também GRÖNING, Gert 1997: Ideological Aspects of Nature Garden Concepts in Late Twentieth Century Germany, WOLSCHKE-BULMAHN, Joachim (ed.), Nature and Ideology, Natural Garden Design in the Twentieth Century, Dumbarton Oaks Colloquium on the History of Landscape Architecture, XVIII, 220-248, Washington, D.C.; veja também GRÖNING, Gert 1996: Der Überfall auf Polen und seine Auswirkungen auf das Konzept der deutschen Landespflege, GRÖNING, Gert (ed.), Planung in Polen im Nationalsozialismus, 91-105, Berlim.

${ }^{7}$ Veja o ensaio do organizador da conferência RADKAU, Joachim 2003: Naturschutz und Nationalsozialismus - wo ist das Problem?, handout for participants of the conference "Naturschutz und Nationalsozialismus, Erblast im demokratischen Rechtsstaat?", Berlim, 3-5 Julho 2002, 12 p. Radkau escreveu "que os nazistas em sua maioria eram mais ou menos seres humanos normais" (p. 2). Dado o sistemático extermínio de milhões de pessoas que os nazistas consideravam sub-humanos, esta afirmação é uma vergonha.

${ }^{8}$ Veja GRÖNING, Gert 2002: Naturschutz und Nationalsozialismus, Lorenz, Klaus-Peter (ed.), Politische Landschaft - die andere Sicht auf die natürliche Ordnung, 159-187, Duisburg.

${ }^{9}$ Veja ELIAS, Norbert 1976: Über den Prozess der Zivilisation, dois volumes, Frankfurt am Main.
} 
FIGURA 5 - A "CASA DE CHÁ DO FÜHRER" PERTO DE BERCHTESGADEN BAVIERA, PINTURA DE MATTHIAS KOEPPEL, BERLIM, 1985. O LÍDER NACIONAL SOCIALISTA, ADOLF HITLER, TEVE UMA CASA DE CHÁ CONSTRUÍDA PARA SI MESMO NOS ALPES ALEMÃES. NO DECORRER DA SEGUNDA METADE DO SÉCULO XX ELA SE TORNOU UMA IMPORTANTE ATRAÇÃO TURÍSTICA, ESPECIALMENTE PARA AQUELES QUE SIMPATIZAM COM O NACIONAL SOCIALISMO NA ALEMANHA. A MÃO LEVANTADA DE UM DOS VISITANTES NA FOTO VISUALIZA ISSO.

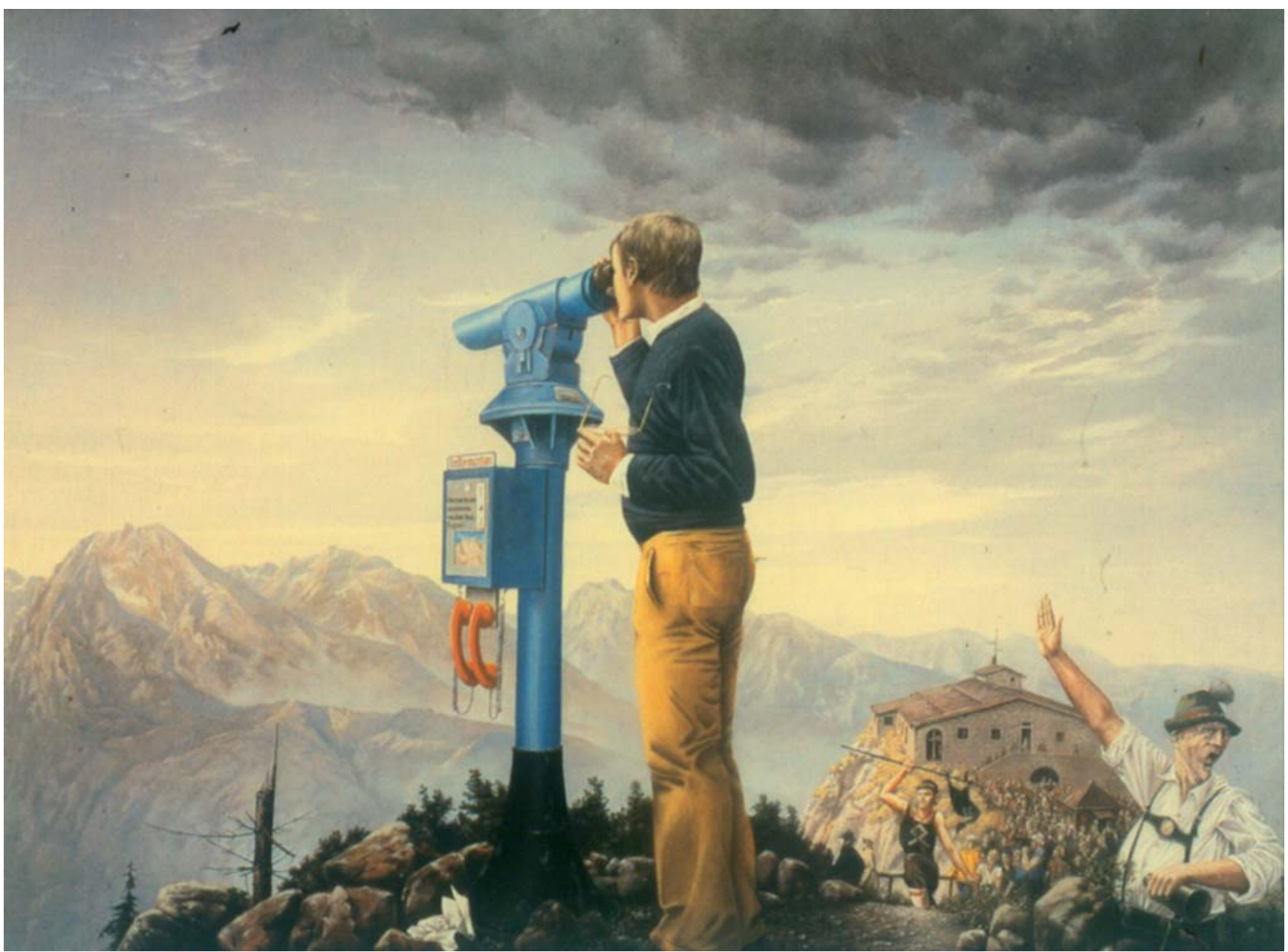

\section{OS DIVERSOS SIGNIFICADOS E VALORES AMBIVALENTES LIGADOS AOS ELEMENTOS DO ESPAÇO LIVRE}

Para mim o interesse na arborização urbana está ligado à idéia da cultura do jardim e dos espaços livres. A cultura do jardim e do desenvolvimento dos espaços livres está ciente e tem trocas de longo alcance com a natureza não humana. Como qualquer outra atividade humana, as atividades relacionadas ao jardim e aos espaços livres podem ser questionadas em quanto deliberadamente e em que extensão ela pode ser concebida.

Nesse caso tenho como garantido que aqueles que compartilham desses padrões por si mesmos devem perguntar aos outros o que eles pensam a respeito de tais regras estabelecidas. A cultura do jardim e do espaço livre tem ponto de partida em um estado democraticamente constituído. Aqueles que advogam isso compreendem que seus interesses competem com outros interesses legítimos relacionados ao espaço livre numa sociedade. Atividades respectivas podem ser afetadas num discurso racional. Para implementar seus objetivos, a cultura do jardim e do desenvolvimento do espaço livre explicitamente usa resultados da pesquisa em ciência social e história da arte. A cultura do jardim e do desenvolvimento do espaço livre adota aspectos da história, do design, e do uso de jardins, parques e outros espaços abertos intermediados socialmente.

Isto é diferente de um planejamento da paisagem orientado "ecologicamente", o qual esta baseado só em resultados cientificamente aplicados e que reivindica agir no interesse de um conveniente objetivo no interesse "ecológico" da "natureza". Quando os seres humanos reivin- 
FIGURA 6 - SÃO PAULO, AVENIDA PAULISTA, 1910 E 1987. A AVENIDA PAULISTA EM 1910 NA FOTO SUPERIOR E EM 1987 NA FOTO DE BAIXO. GOSTARIA DE CHAMAR SUA ATENÇÃO PARA A ARBORIZAÇÃO DA AV. PAULISTA COM A DUPLA FILA DE ÁRVORES QUE FOI PLANTADA EM SUAA INAUGURAÇÃO EM 1910. NÃO SEI PORQUE AS ÁRVORES NÃO ESTÃO MAIS LÁ. VALERIA A PENA PESQUISAR PARA SEGUIR A HISTÓRIA DESSAS ÁRVORES DE MODO A ENTENDER O QUE PODE OCORRER COM A IDÉIA DA "ARBORIZAÇÃO URBANA".
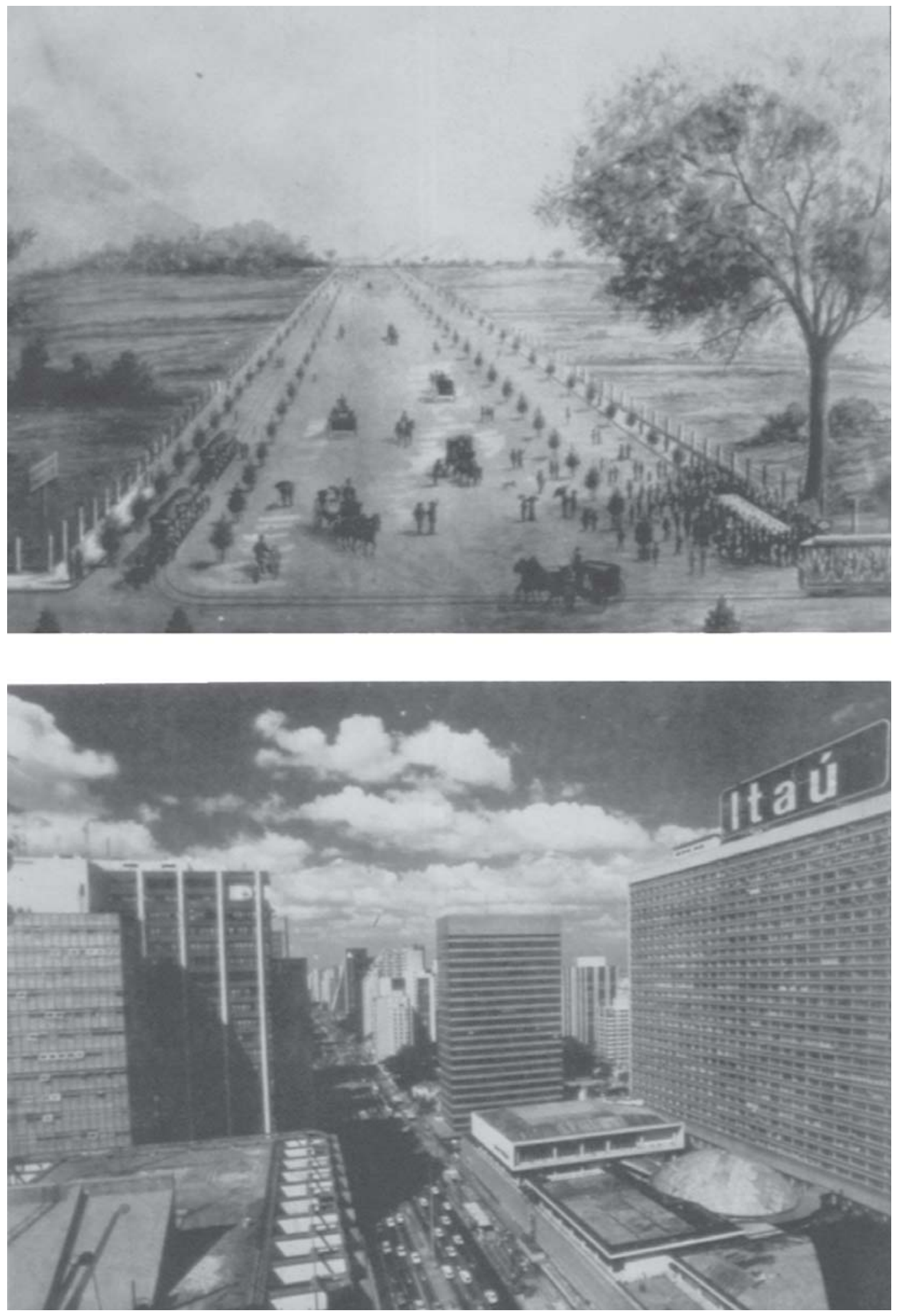
dicam planejar no interesse da natureza eles omitem que isto não é nada mais que um dos muitos outros interesses humanos. A natureza que antecede a história humana e a civilização é a natureza "que hoje em dia não existe em nenhuma parte”, como Karl Marx (1818-1883), o filósofo social alemão e teórico chefe do socialismo e do comunismo concebeu já no século XIX.10

[nota do apresentador: nesse momento da conferência Gert Gröning mostra a Av. Paulista em São
Paulo em dois momentos e convida à uma reflexão sobre os interesses humanos - Figura 6].

Assim a natureza não humana, como o solo, a água, o ar, e mais plantas e animais, pode ser entendida somente como um produto das trocas sociais. Noções de "natureza" são sempre moldadas pela percepção individual a qual é intermediada socialmente e culturalmente.

Em recente pesquisa, Uwe Schneider e eu mostramos como a percepção da "paisagem" da charneca

FIGURA 7 -TERRITÓRIO INDÍGENA, EM ALGUM LUGAR DOS EUA, REVISTO, PINTURA DE DAVID P. BRADLEY, 1994, ACRÍLICO SOBRE TELA. UMA MUDANÇA DA "PAISAGEM" VISTA COM OS OLHOS DE UM PINTOR E SEMELHANTEMENTE EM CONTRADIÇÃO COM AQUILO QUE MUITOS ACREDITAM SER TERRITÓRIO INDÍGENA NOS EUA.

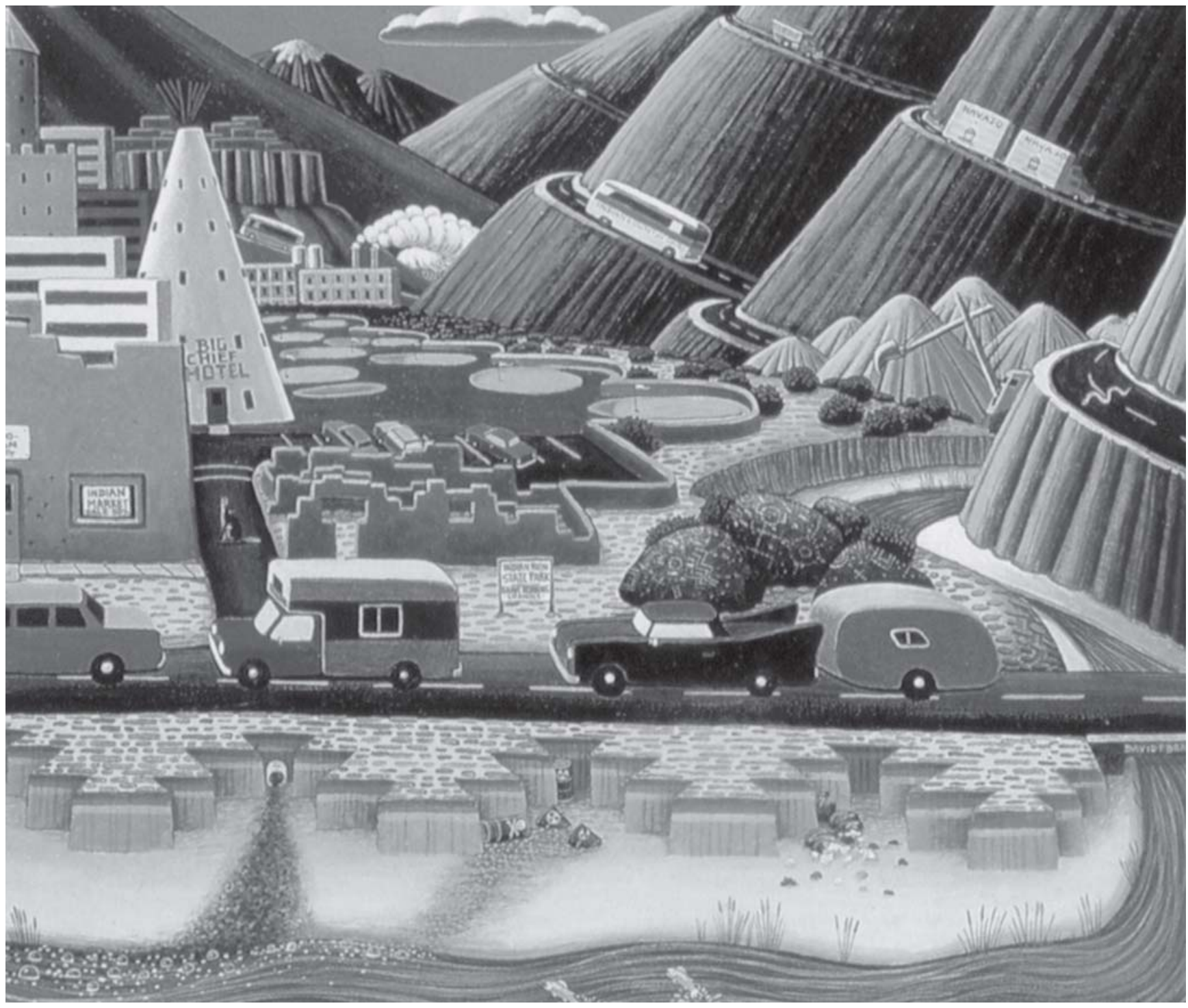

${ }^{10}$ MARX, Karl e Friedrich ENGELS 1959: Werke, volume 3, Berlim; veja também GROH, Ruth e Dieter GROH 1993: Natur als Masstab - eine Kopfgeburt, Merkur, 47, 11, 965-979. 
mudou no último século aproximadamente. ${ }^{11} \mathrm{~A}$ charneca é uma forma de vegetação regularmente bastante espaIhada na Europa. Num processo relativamente complexo sua percepção mudou de uma área muitas vezes desprezada no ultimo século XIX alemão para uma área bastante apreciada no decorrer do século XX.

Estas mudanças foram muito afastadas do "natural". Literatura, pintura, geografia de plantas, fotografia, arquitetura paisagística, ideologia racista, turismo, psicologia e muitos outros aspectos foram envolvidos.

Sabemos que muitas dessas mudanças, por quaisquer razões, não foram particularmente bem pesquisadas no que diz respeito à cultura do jardim e do desenvolvi- mento dos espaços livres. Isto inclui a mutável preferência por certos tipos de paisagens bem como daquela por plantas.

Relativamente a paisagens, os Alpes, e em relação a plantas, as "tulipas", são os maiores exemplos de mudanças de percepção. Sabe-se bem o quanto os Alpes tornaram-se numa grande atração turística no decorrer do século XX e quanto as pessoas enlouqueceram com as tulipas, especialmente na Holanda, alguns séculos atrás.

Isso vale também para a noção de paisagem, uma categoria semelhantemente e completamente especial. ${ }^{12}$ A imprecisão da categoria torna-se muito pior quando

FIGURA 8 -ÁRVORES E CHAMINÉS, CARTOON ANOS 1970, A DIFERENTE PERCEPÇÃO DEPENDENDO DO INTERESSE
DE ALGUÉM. AQUI A PESSOA COMUM VÊ DUAS ÁRVORES, UM INDUSTRIAL, PORÉM, IMAGINA DUAS FUMEGANTES CHAMINÉS.

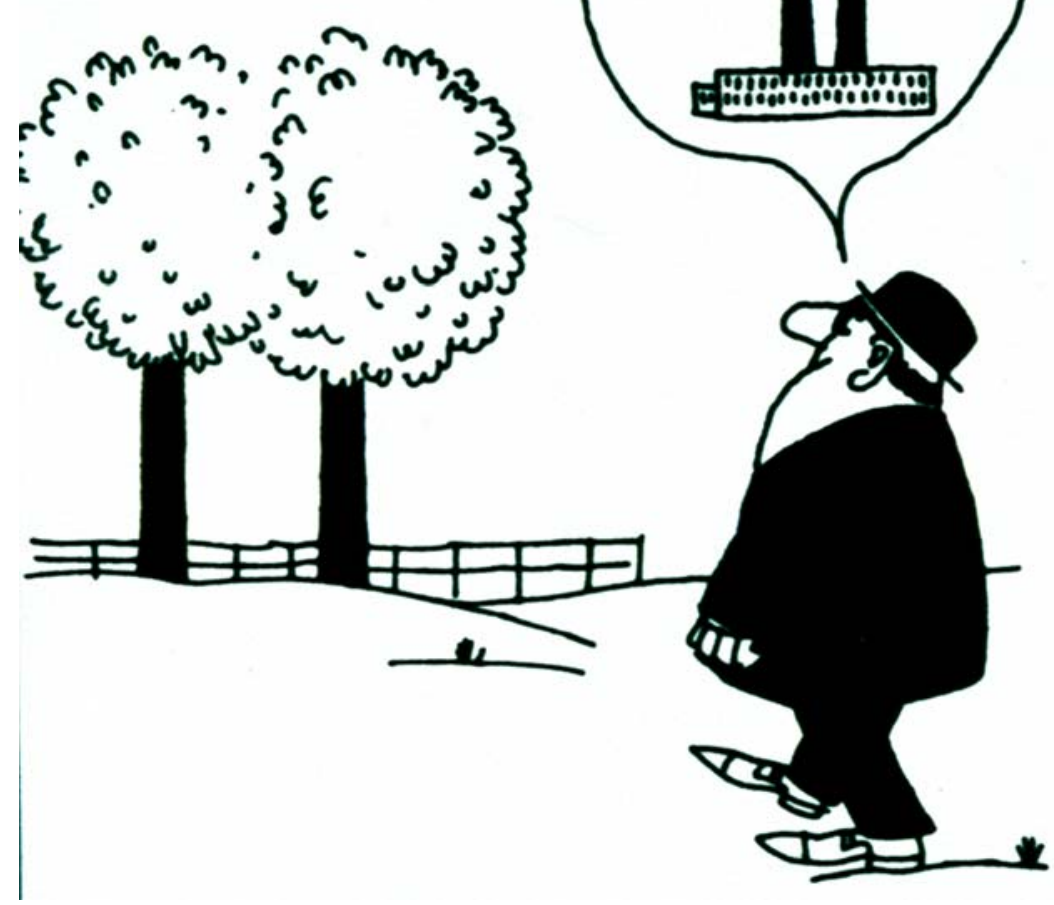

${ }^{11}$ Veja GRÖNING, Gert e Uwe SCHNEIDER 1999: Die Heide in Park und Garten. Zur Geschichte und Bedeutung des Heidemotivs in der Gartenkultur. Grüne Reihe-Quellen und Forschungen zur Gartenkunst, volume 19, Worms. Veja também GRÖNING, Gert e Uwe SCHNEIDER (eds.) 2001: Gartenkultur und nationale Identität, Grüne Reihe - Quellen und Forschungen zur Gartenkunst, volume 22, Worms.

12 Veja GRÖNING, Gert 2003: Über den Landschaftsbegriff, Arbeitsgruppe Mensch - Umwelt -Technik TU Berlin (Ed.), „Was ist der Mensch?", Schriftenreihe Technik und Gesellschaft, volume 5, 60-76, Aachen. 
usada em combinações de palavras tais como ecologia da paisagem e arquitetura da paisagem, como conferir à ecologia e arquitetura com as quais se sentisse relacionada, um status de eternidade e de atemporalidade. Todavia, a percepção da "paisagem" nunca foi e nunca será estável (Figuras 7 e 8).

Ecólogos da paisagem, planejadores da paisagem e outros que acreditam que podem trazer uma contribuição para a melhoria da situação dos espaços livres para outras pessoas poderiam, em qualquer lugar que estejam trabalhando, tentar entender o significado de espaço livre para os diversos grupos da população.

Para a reputação profissional seria útil ter cuidado com o significado que alguém deu a vários espaços livres e elementos de espaços livres, tais como árvores, por exemplo, no decorrer de sua própria vida.

Como mostra a pesquisa é de bom alvitre ser modesto nas suposições relativas ao interesse, o uso, a apreciação do design e da história dos espaços livres bem como do conhecimento de plantas, solo, água, ar, e muitos outros fatores, sem mencionar seu relacionamento.

Qualidades e quantidades de espaços livres podem ser apreciadas de maneira quase diferente em várias situações sociais e culturais. Embora, para ser capaz de descobrir tais variações, referir-se a elas na perspectiva de um cientista social, um designer e de um usuá-rio é uma atividade significativa da cultura do jardim. Razoavelmente e em alguns países é possível reportar-se a material pesquisado empiricamente.

Por volta dos anos 1970 na Alemanha algumas pessoas associaram-se em grupos intitulando-se a si mesmos "Bürgerinitiative", iniciativa de cidadãos. Estes grupos freqüentemente divulgaram seu interesse em padrões de espaços livres altamente quantitativos e altamente qualitativos não só nas cidades, mas, também, nas áreas rurais.

Com o passar dos anos fora essas "iniciativas dos cidadãos" formou-se um movimento "verde" que, com o tempo, tomou parte do processo político-partidário conhecido como democracia. Então, pela primeira vez, depois da república de Weimar, o significado de espaços livres voltou a ser novamente matéria de interesse público. Essa situação ocorreu nas grandes cidades e nas aglomerações urbanas. Nesses lugares o número de votos em eleições democráticas tornou-se o suficientemente grande para, pela primeira vez, influenciar a política de espaços livres no nível local, e posteriormente, nos primórdios dos anos 1980, também no nível estadual e federal.

Não sem surpresa alguns interesses emitidos ficaram além do que outros pensaram que ele podia suportar. Freqüentemente está relacionado com áreas rurais com um passado agrícola. Aqui os eco-urbanos encontraram às vezes considerável resistência, senão hostilidade. [nota do apresentador: nesse momento da conferência Gert Gröning mostra mapas da Alemanha sobre as mudanças da relação área/habitante em relação áreas mais naturais e áreas de espaços livres e faz o comentário a seguir, mostrando a transformação do interesse da população].

(...) tal interesse renovado refletiu-se em relatórios oficiais como, por exemplo, o "Bundesraumordnungsbericht", o Relatório Federal para o Ordenamento Espacial, de 1974; para áreas próximas do natural, as categorias eram de menos de 500 metros quadrados por pessoa a 4000 metros quadrados e mais, e para os espaços livres as categorias vão de menos que 1000 metros quadrados para mais de 8000 metros quadrados.

Embora a assim chamada consciência ambiental tenha ganho considerável popularidade nos anos 1980 , parece característico para muitos eco-urbanos que eles dividem uma considerável relação ambivalente com a natureza não humana como ela está ainda presente em algumas das mais remotas áreas em seus países.

Eles tendem a subestimar que mesmo a agricultura que se pode considerar uma espécie de atividade pré-industrial, tornou-se completamente industrializada. Assim, um crescente número de pessoas tem de admitir que a tendência de longa data em direção à urbanização e industrialização que impulsionam por suas várias atividades, também abarca a agricultura. Aqui eles parecem tornar-se conscientes de uma discrepância (Figura 9).

A natureza de espaços livres que tem sido apresentada em escolas e nos museus de arte como "paisagens" dos séculos XVIII e XIX difere frontalmente das áreas de agricultura industrializada próxima das cidades nas quais eles levam uma vida relativamente confortável (Figura 10).

Alguns assumem esta experiência de discrepância em público. Esta é uma das faces do relacionamento com a natureza não humana. Deste ponto alguém poderia abordar a idéia de criar um paraíso. Apesar de que os cristãos sabem que têm sido conduzidos para o paraíso há muito tempo. Alguns podem ponderar sua própria distância daquilo que eles consideram natureza e podem imaginar que esta natureza permanecerá para sempre fora de seu alcance. O melhor que podem fazer é sonhar com ela, escrever sobre ela, compô-la, colocá-la em cena, pintá-la ou idolatrá-la.

[nota do apresentador: nesse momento da conferência Gert Gröning mostra um slide com uma pintura que reflete a expulsão de Adão e Eva do Paraíso e faz o comentário a seguir].

(...)expulsão do Jardim do Éden, 1827-1828, pintura do pintor paisagista americano Thomas Cole (1801- 
FIGURA 9 - NOVOS MOINHOS DE VENTO EM ÁREAS VARRIDAS PELO VENTO EM MOORHAUSEN, BAIXA SAXÔNIA ALEMANHA. NOVOS MOINHOS DE VENTO, PRÓXIMO DAS MARGENS DO MAR DO NORTE ONDE HÁ FORTES VENTOS. OUTRO SINAL DE UMA AGRICULTURA INDUSTRIAL.

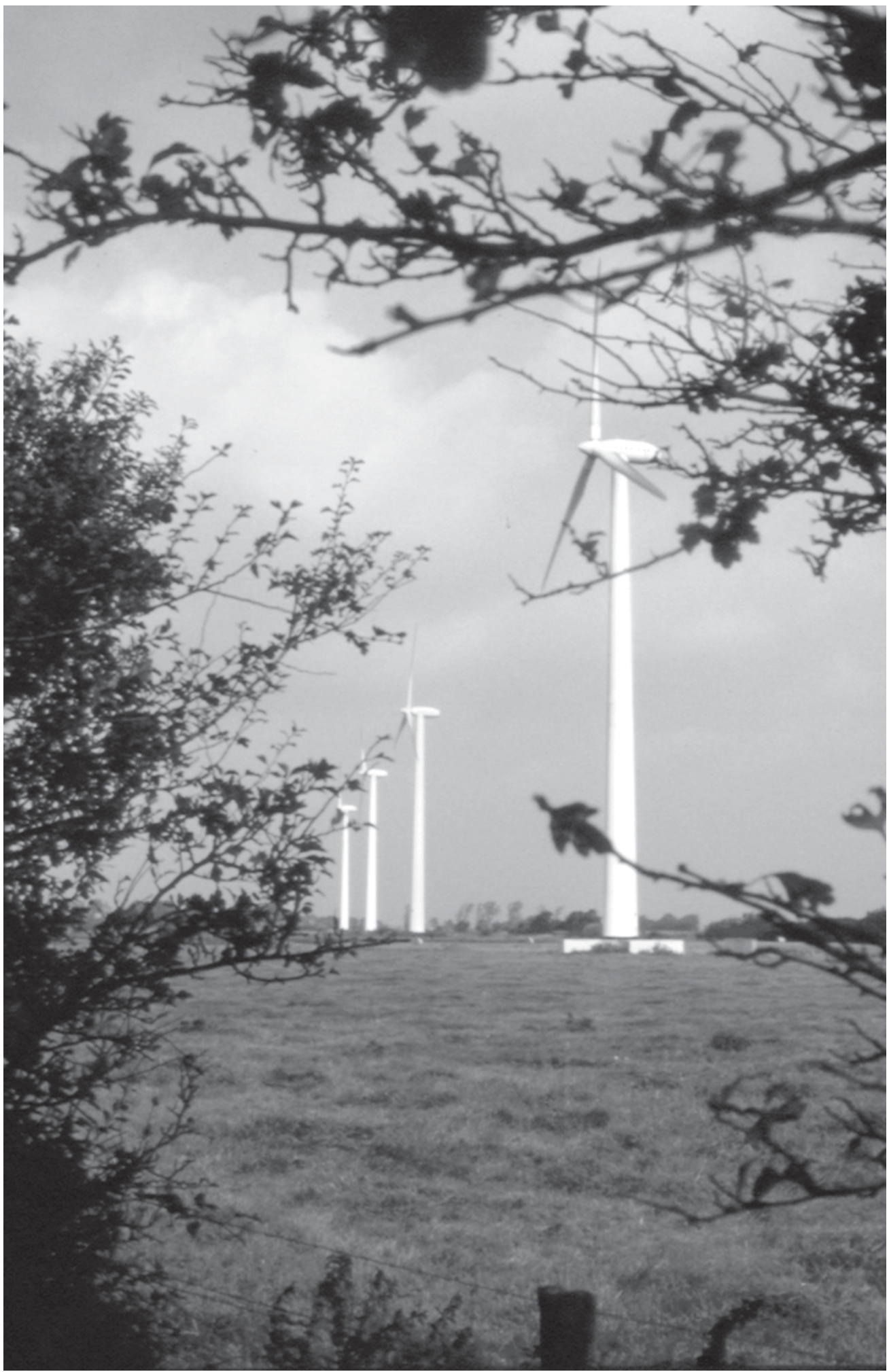

FOTO: GERT GRÖNING 
FIGURA 10 - TAMBÉM OS VALES APRESENTAM-SE CHEIOS DE TRIGO, PINTURA DE 1865 DE RICHARD REDGRAVE, 1804-1888. A AGRICULTURA COMO ALGUNS PLANEJADORES DA PAISAGEM E ECOLOGISTAS TALVEZ VENHAM A "TOLERAR”; UMA SITUAÇÃO RURAL CONVENIENTEMENTE PACATA, NADA DAS CONDIÇÕES SOCIAIS INJUSTAS SOB AS QUAIS AS PESSOAS TÊM DE TRABALHAR, ESTÁ EXPRESSA NA PINTURA.

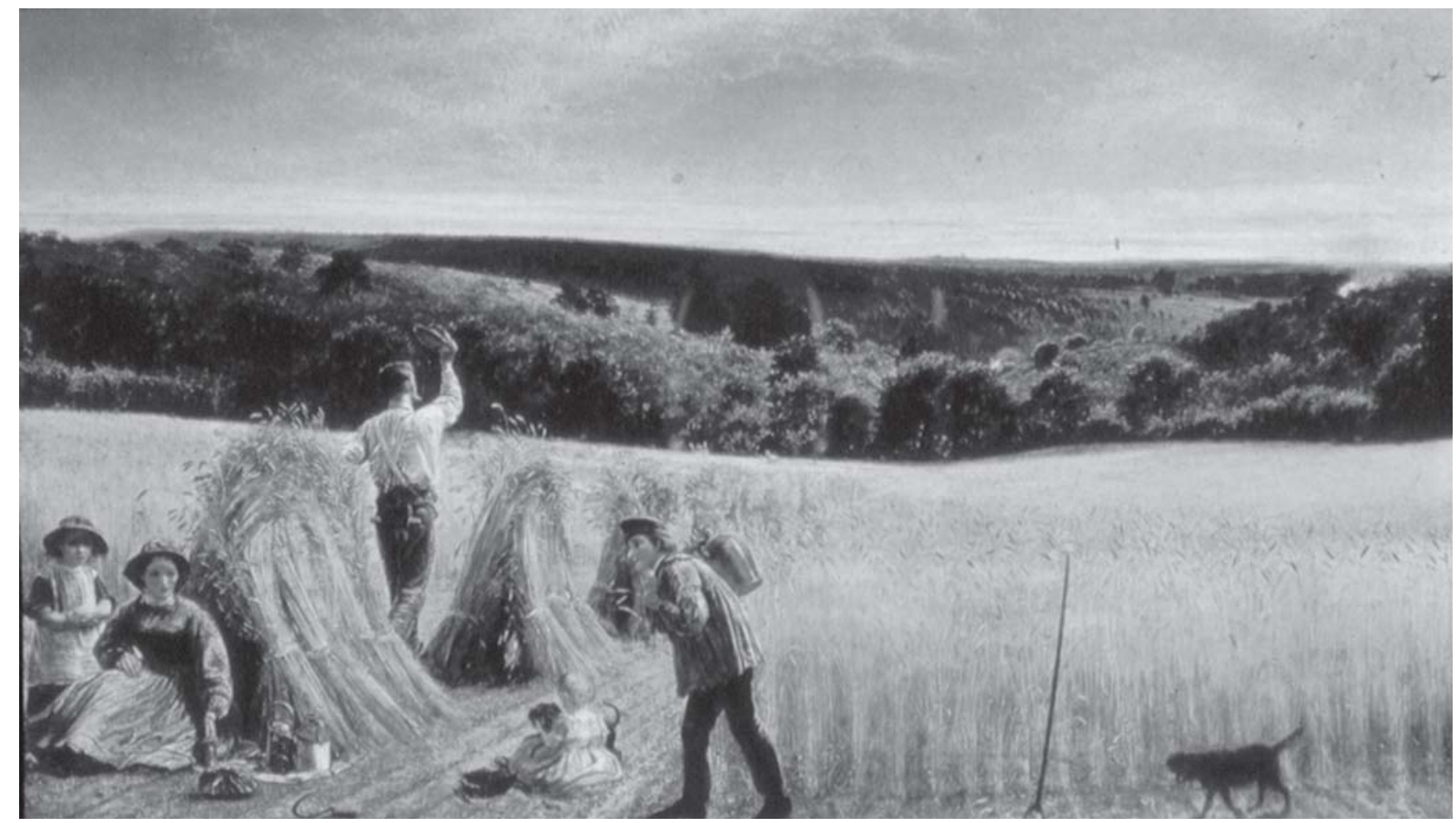

1848). Foi pintada numa época em que uma considerável mudança social ocorria nos EUA. A pintura pode causar interesse novamente no começo do século XXI depois do ataque terrorista ao World Trade Center na cidade de Nova York, ao Pentágono em Washington D.C., e a queda do avião seqüestrado perto de Pittsburgh em 11 de setembro de 2001, o que levou muitos a se sentirem expulsos de sua confortável existência urbana.

Muitos imaginaram que não há um caminho para o paraíso, e alguns podem ainda rejeitar a idéia de estar sempre num paraíso. Muitos de nós não estamos interessados em viver na natureza real. Da nossa história de civilização e urbanização aprendemos que estaremos melhor se percebermos esta natureza não humana seletivamente e só se ela estiver preparada para as nossas maneiras de percepção e experiência.

Assim "próximo da natureza" é uma categoria completamente absurda se se quiser colocar a cultura do jardim e o desenvolvimento dos espaços livres sem a estrutura das atividades políticas e sociais. O que cada um pode fazer é tentar colocar-se a si mesmo de uma forma que permita ver e refletir as mudanças na percepção da "natureza" que acompanha sua vida relativamente aos diversos esforços para ter um sentido do tipo de apropriação da natureza considerada necessária, para o desfrute tanto espiritual como material.
Quando eu tento imaginar o que o século XXI deve ter guardado para a cultura do jardim, então não deve haver um caminho muito longo a percorrer para desenhar suas próprias flores, arbustos e árvores. Que conseqüências isto terá, eu não sei. Todavia, eu penso que seria interessante àqueles que estão interessados na cultura do jardim e do desenvolvimento de espaços livres começarem a pensar nessas questões. Como eu simplesmente indiquei, nunca teve e nunca terá uma posição imutável. Assim tentando dar um sentido, entendo a cultura do jardim e do desenvolvimento dos espaços livres como parte de um caminho para a democracia (Figura 11).

\section{A CULTURA DO JARDIM E OS ASSUNTOS DO ESPAÇO LIVRE COMO TEMAS POLÍTICOS EM SOCIEDADES CONSTITUÍDAS DEMOCRATICAMENTE}

Apesar de ter sido explícito a respeito do significado relativo social e político da cultura do jardim e do desenvolvimento dos espaços livres, há uma infinidade de assuntos relativos às sociedades urbanizadas do século XXI. A cultura do jardim e do desenvolvimento dos espaços livres pode participar do contínuo processo de civilização e urbanização. Todavia, é necessário sobria- 
FIGURA 11 - UMA CENA URBANA CONTRA A ARBORIZAÇ̃̃O. ELE: "MUITO BOA ESTA MARIPOSA DA CASTANHEIRA". ELA: "AFINAL TEREMOS SOL DE NOVO" (ASTREIN DIE KASTANIENMOTTE, ENDLICH WIEDER SONNE); UMA REAÇÃO A UM INSETO QUE ESTÁ APTO A MATAR CASTANHEIRAS EM ÁREAS URBANAS; FREQÜENTEMENTE AS ÁRVORES TENDEM A ESCURECER APARTAMENTOS DOS PISOS MAIS BAIXOS EM EDIFÍCIOS ALTOS ESPECIALMENTE EM CONJUNTOS HABITACIONAIS URBANOS.

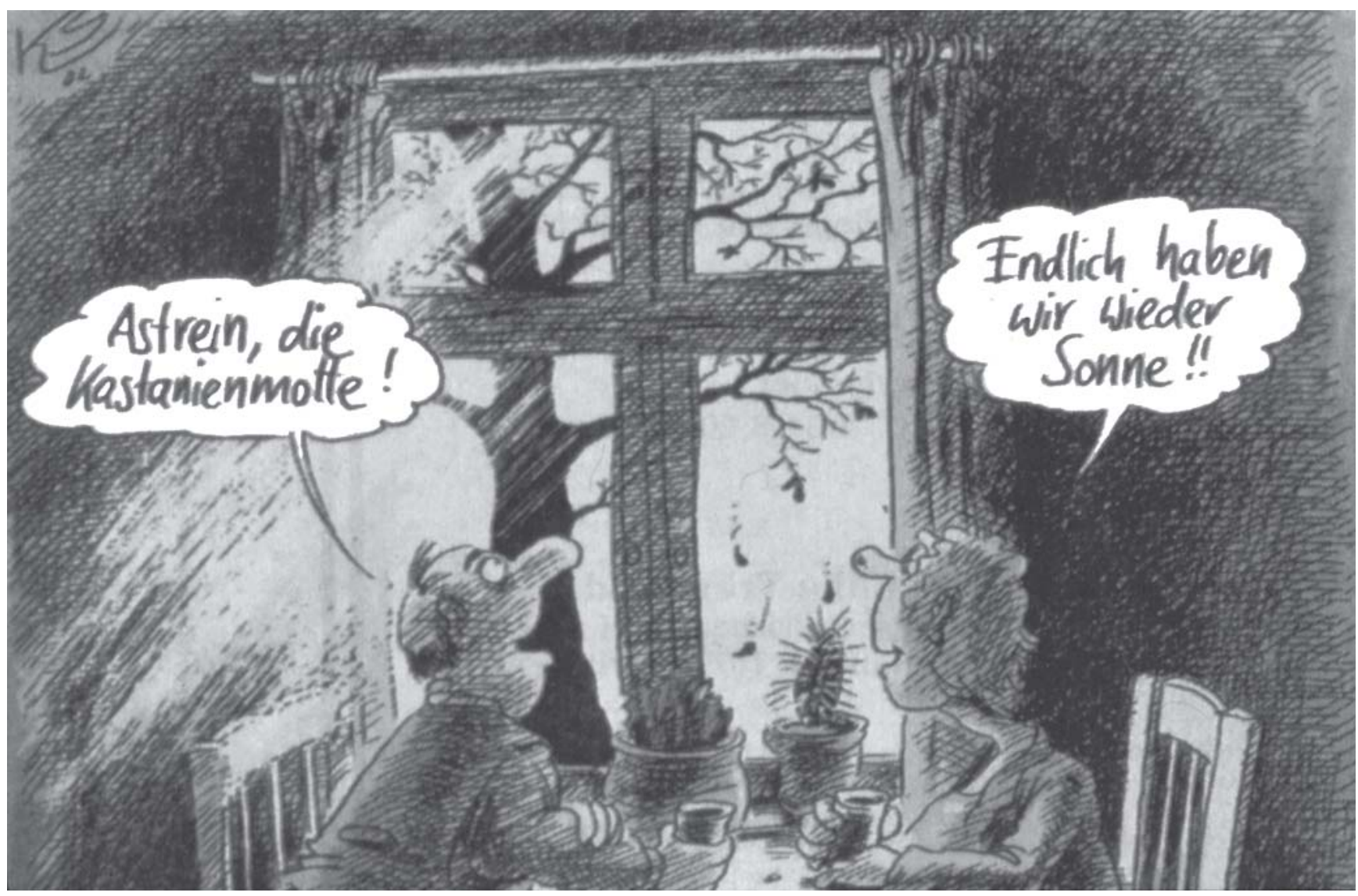

CARTOON DE KARL STUTTMANN (2002)

mente avaliar o papel que este campo pode desempenhar nos vários estágios.

Dois pontos parecem ter especial significado. Primeiramente considero o mais importante conversar com as pessoas, descobrir seus interesses e oferecer assistência; então autorizar mais uma outra análise ecológica ou mais um outro estudo de biodiversidade. Em segundo lugar, é mais importante aplicar resultados cientificamente provados e criatividade artística do que invocar idéias místicas sobre jardins e paisagens.
Como o movimento "Kleingarten" na Alemanha prova há mais de cem anos, jardinagem numa associação é uma poderosa faceta política e social da cultura urbana do jardim. ${ }^{13}$

Numa recente conferência em Berlim, Alemanha, ${ }^{14}$ representantes de lugares tão distantes como o Japão, Bangladesh, Rússia, Estados Unidos da América e de inúmeros outros lugares, mostraram que existem muitos países em todo o mundo onde se manifestam interesses similares ao do movimento "Kleingarten" na Alemanha.

${ }^{13}$ Veja GRÖNING, Gert 2000: Aspects of Allotment Gardening Politics in Berlin, Germany, between 1985 and 1995, Acta Horticulturae, volume 523, 167-179; veja também GRÖNING, Gert 1996: Aspects of Community Gardening in Germany, City Farmer, Canada's Office of Urban Agriculture, City Farmers Urban Agriculture Notes, Internet Publication, Vancouver, British Columbia; veja também BERTRAM, Christian e Gert GRÖNING 1996: Leipziger Schrebervereine und ihre Gesellschaftspolitische Orientierung zwischen 1864 und 1919 , Frankfurt am Main; veja também GRÖNING, Gert e Joachim WOLSCHKE-BUHLMANN 1995: Von Ackermann bis Ziegelhuette, Ein Jahrhundert Kleingartenkultur in Frankfurt am Main, Studien zur Frankfurter Geschichte, volume 36, Frankfurt am Main; veja também GRÖNING, Gert 1974: Tendenzen in Kleingartenwesen dargestellt am Beispiel einer Grossstadt, Beiheft 10, Landschaft + Stadt, Stuttgart.

${ }^{14}$ Veja MEYER-RENSCHHAUSEN, Elizabeth MUELLER, Renate e Petra BECKER (eds.) 2002: Die Gärten der Frauen, Zur sozialen Bedeutung von Kleinstlandwirtschaft in Satadt und Land weltweit, Frauen Gesellschaft Kritik, volume 35, Herbolzheim. 
FIGURA12 - FORÇA 2000 - PROGRAMA DOS AMIGOS DO JARDIM DE BERLIM. O PROGRAMA PODER 2000 DA ASSOCIAÇÃO BERLINENSE DE JARDINAGEM DE LOTES, QUE INCLUI UMA LISTA DE ATIVIDADES NOS NÍVEIS LOCAL, DISTRITAL E DA CIDADE INTEIRA. NO COMEÇO DO SÉCULO XXI EXISTEM PERTO DE 100.000 JARDINS EM LOTES (KLEINGARTENANLAGE) EM BERLIM O QUE DÁ UMA PROPORÇÃO DE APROXIMADAMENTE 35 HABITANTES POR JARDIM EM LOTES.

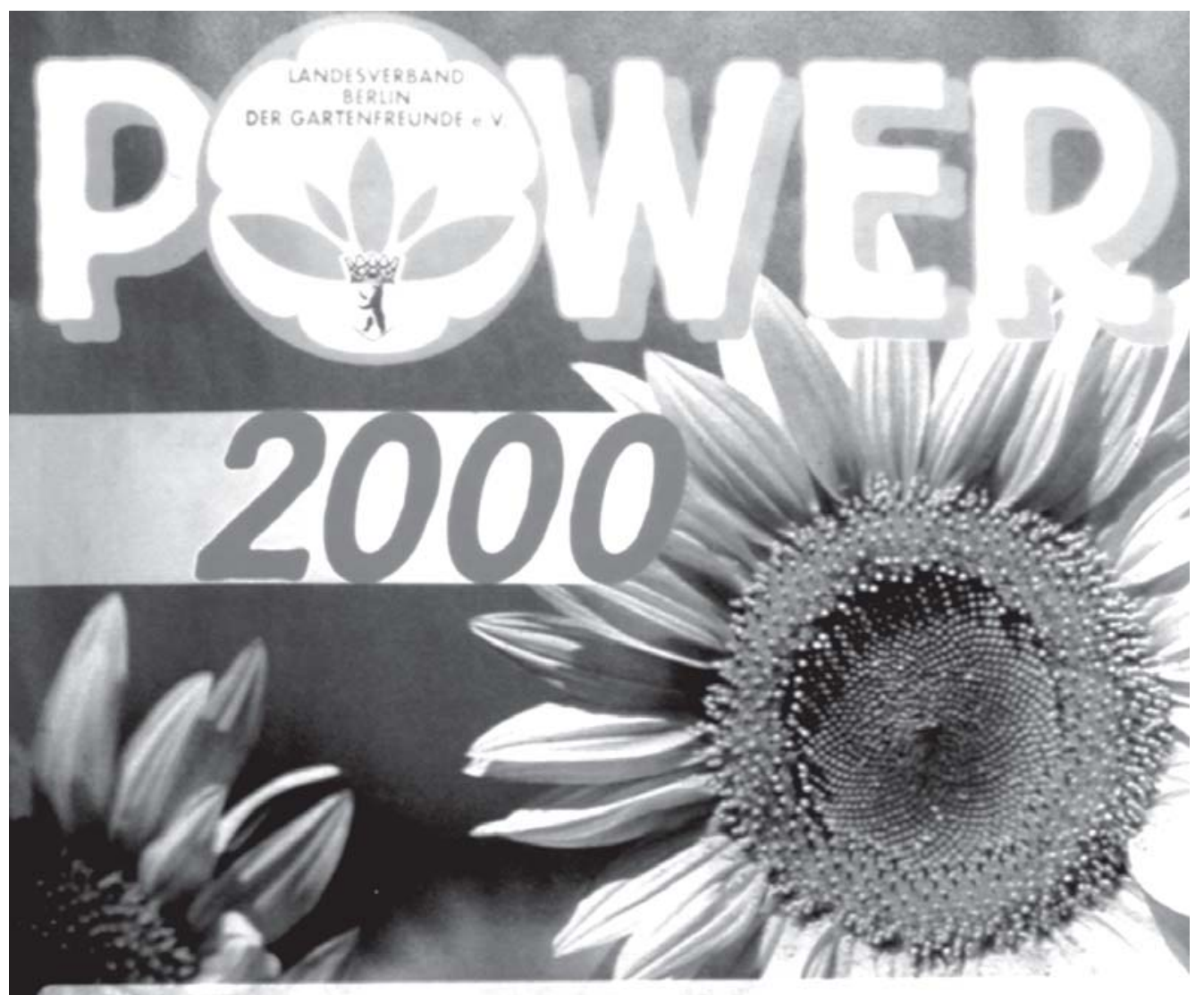

Liebe Gartenfreundinnen, liebe Gartenfreunde,

der Wechsel in das Jahr 2000 ist mit euphorischen Erwartungen, angstlicher Skepsis und wahren Horrorszenarien überfrachtet.

Was wird uns dieses Jahr mit der symbollischen Zahl bringen? Sicher Ûberraschungen, gute wie schlechte, wie es sle jedes Jahr gibt.

In unserer vernetzten und computerisierten Welt móglicherweise ein par mehr als ûblich beim übergang ins neue Jahr. Y2K - dle verflixten Nullen.

Wir, Int Landesverband Berlin der Gartentreunde. haben für die Entwicklung des Berliner Kleingartenwesens weder angstilche Skepsls noch euphorische Erwartungen aber eine ganze Menge kräftiger Ideen, die uns voranbringen werden. Pover 2000 steht über unserem Programm, mit dem wir unseren Anspruch unterstreichen, bel der Entwicklung dieser Stadt oktly mitzuwirken, aber auch unsere interessen zum Wohie aller Bürger

hart zu vertreten.

Aut den folgenden Selten geben wir Ihnen einen Weinen Überblick uber seplante zentrale und bezirkliche Aktivitäten.

Wir bitten Sie alle. jede Gartenfreundin und Jeden Gartentreund, werden Sie aktlv, entwickein Sie in Ihrer Kleingartenanlage, in Ihrem Bezirksverband ergänzende Aktionen. Nehmen Sle tell an dem viel. faltigen Gemeinschaftsleben unserer Organisation. Laden Sie Freunde, Bekannte und Nachbarn ein. damit sle aus eigener Anschauung sich ein Bild machen kobnnen und erleben, was unser Slogan aut der kommenden internotionalen Grinen Woche be deutet: _Kleingärten - das Lächeln der Metropole".

In diesem Sinne wìnschen wir allen unseren Mitglledern und freunden viel Glúck fû́r das Jahr 2000,

Fûr den Geschäftstührenden Vorstand jursen Hur:

Präsident des Landesverbandes Berlin der Gartentre - ue c V 

ALEMÃ "KLEINGÄRTEN".

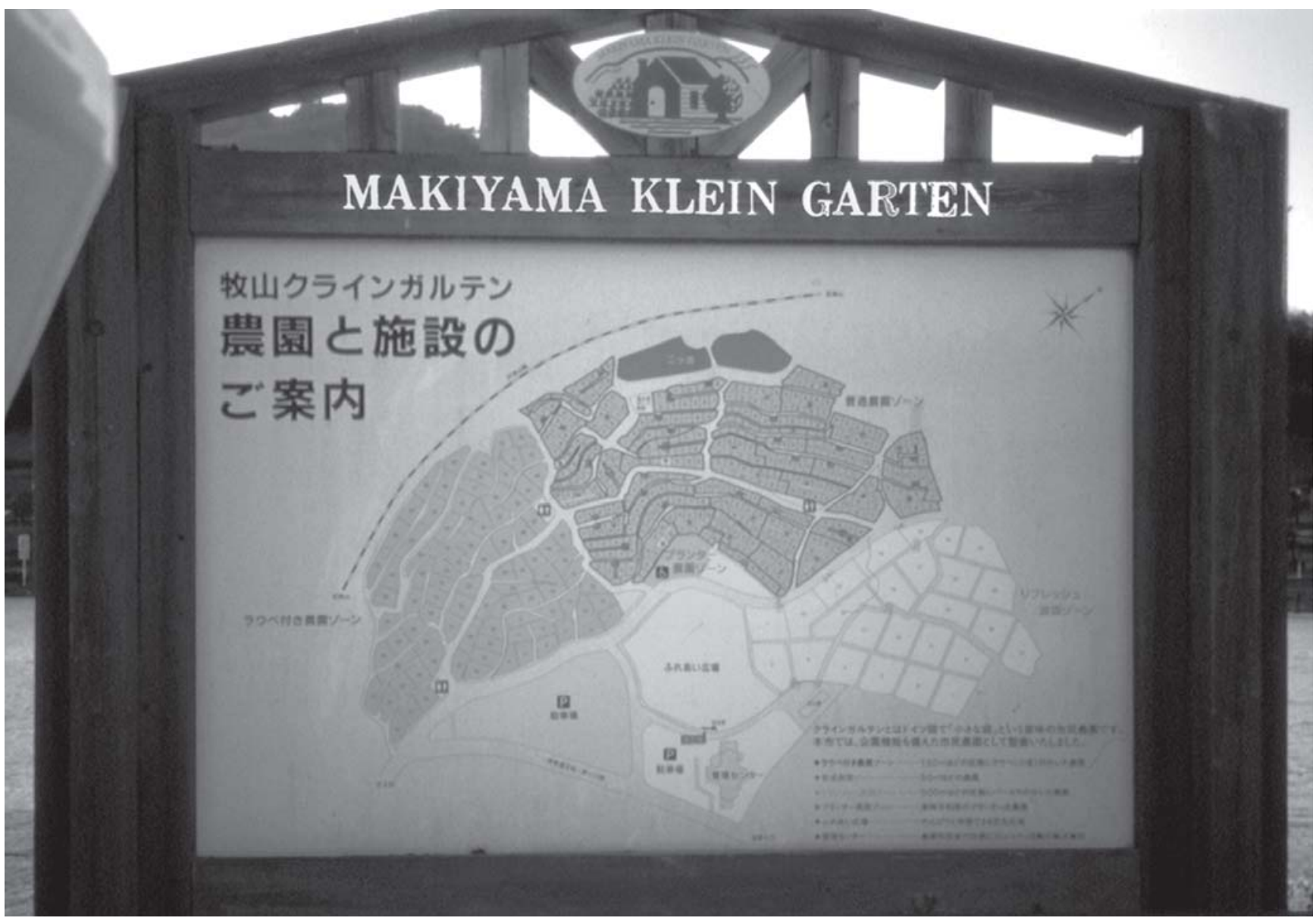

FOTO: GERT GRÖNING

No Japão, por exemplo, onde muitos europeus e, pode ser, muitos de vós brasileiros também, tendem a pensar que não haja espaço de nenhuma maneira para a jardinagem, um bom número de lugares para "Kleingarten" foram estabelecidos em anos recentes. Ainda mais, o crescente interesse nesses assuntos na sociedade japonesa largamente urbanizada, está refletido em um novo jornal, o Jornal da Sociedade Japonesa de Relacionamento Plantas-Pessoas que foi lançado em $2001 .{ }^{15} \mathrm{E}$ mais do que isso, como um dos poucos países no mundo, a democracia japonesa emitiu duas leis que regulam a jardinagem de loteamento nessa nação (Figura 13).

$\mathrm{O}$ ano passado quando participei do VII Congresso Brasileiro de Arborização Urbana em Belém, Pará, soube de um estudo que tratava das necessidades da jardinagem pelos pobres em Belém. ${ }^{16}$ Todavia, em muitos casos, em toda parte, as dimensões sociais, políticas e econômicas não são (ainda) compreendidas apropriadamente.

No Japão e em muitas outros lugares ao redor do mundo algumas árvores urbanas são visivelmente veneradas.

Desfrutar da cultura do jardim, o que inclui arvores e outros elementos relativos ao espaço livre num ambiente urbano, necessita a articulação de tais interesses nos vários corpos políticos das comunidades, distritos, estados e da nação.

Tais interesses também necessitam estar integrados aos programas político-partidários de modo a torna-

${ }^{15}$ Veja Journal of the Japanese Society of People-Plant Relationships, 1, 2001, 1.

${ }^{16}$ Veja FRÉRE, Nathalie; LUDOVINO, Rui Manuel Rosário e Paulo Fernandes da SILVA MARTINS 1998 (?): Agricultura urbana em Belém - Pará, Universidade Federal do Pará, Brasil. 
rem-se realidade em sociedades democraticamente constituídas. ${ }^{17}$

Idéias sobre a cultura do jardim e do desenvolvimento dos espaços livres não deve ser apresentada completamente independente de outros assuntos ou até como uma espécie de programa mártir, e nunca no setor público. Por exemplo, aqueles que estão ativamente providenciando espaços livres para a cultura do jardim, para "playgrounds" para crianças, para árvores, etc., podem e devem integrar temas sobre prevenção do crime em ambientes urbanos. Se não o fizerem, os valores sociais e culturais que eles associam com vários tipos de elementos dos espaços livres não serão conhecidos dos políticos e de outros tomadores de decisão.

Ao invés de ética "ecológica" necessita-se da prática social para o planejamento da cultura do jardim e dos espaços livres. ${ }^{18}$ Junto com o dialogar, é um importante instrumento prover planos escritos e projetados em vários níveis de decisão política.

\section{EXEMPLOS DE ATIVIDADES DE PLANEJAMENTO FAVORÁVEIS À CULTURA DO JARDIM E DO DESENVOLVIMENTO DE ESPAÇOS LIVRES NA ALEMANHA}

Compilei numa tabela a que chamei "Esquema de Planos de Espaços Livres" os níveis de planejamento nos quais as atividades em favor da cultura do jardim e do desenvolvimento de espaços livres podem ter lugar na Alemanha (Figura 14).

Sem entrar em detalhes, gostaria de apontar três níveis de planejamento que parecem apropriados para resolver os assuntos do planejamento de espaços livres em sociedades constituídas democraticamente.

Estes níveis não estão tão profundamente separados um do outro como o esquema pode sugerir. O nível um refere-se ao sistema de espaços livres numa região ou cidade (Figura 15).

Outro nível é a estrutura de espaços livres numa cidade ou numa menor unidade política (Figura 16).
O nível três se refere à estrutura de espaços livres que são os elementos que conformam um dado espaço livre (Figura 17).

De certa forma esses planos se referem à invenção no passado século XIX na Alemanha. ${ }^{19}$ Por outro lado eles são um grito longínquo dos planos do passado século XIX desde que tais planos tornaram-se mais e mais refinados.

Se alguém deseja arborizar áreas urbanas e se deseja criar parques e outras áreas de recreação, então tais idéias devem ser incorporadas em vários níveis de planejamento. Isto inclui as vizinhanças, as comunidades, os condados, os estados e a nação como um todo. E à medida que aumenta a integração global, abrange também os correspondentes programas políticos nos níveis sul-americanos, europeus e, por fim, níveis mundiais. ${ }^{20}$

Aqueles que conscienciosamente perseguem o objetivo de estabelecer espaços livres de modo a aumentar o prazer e o desfrutar do meio ambiente, que querem assegurar espaços livres para recreação e proteção da natureza, precisam apresentar sua visão em conceitos, planos e sugestões aos representantes das assembléias federais e estaduais, aos membros dos conselhos comunais e várias outras instâncias envolvidas no processo decisório e em suas comissões.

Assim, por exemplo, desde 2001 a cidade de Bremen implantou sua política de espaços livres na diretriz do que se chamou "Rede Verde Bremen". Em todos os 19 distritos a rede verde existente que inclui áreas verdes, parques, jardins de loteamento, cemitérios, trilhas e campos esportivos, praças urbanas e conexões verdes são assinaladas e avaliadas numa escala de 1:5000. Déficits são analisados de modo a desenvolver propostas de planejamento para o desenvolvimento dos espaços livres dos distritos. Diversamente de outros planos "convencionais" os usuários dos espaços livres participam deliberadamente nesses processos. Através de muitas reuniões de especialistas no local os responsáveis pela autoridade local, os políticos distritais, arquitetos paisagistas e planejadores urbanos, os encarregados pelos departamentos de jardins locais e os re-

\footnotetext{
17 Veja MILCHERT, Juergen 1984: Tendenzen der städtischen Freiraumentwicklung in Politik und Verwaltung, Arbeiten zur sozialwissenschaftlich orientierten Freiraumplanung, volume 5, Munique.

${ }^{18}$ Veja GRÖNING, Gert e Joachim WOLSCHKE-BUHLMAN 1986: Soziale Práxis statt ökologischer Ethik, Zum Gesellschafts- und Naturverständnis in der Jugendbewegung unter besonderer Berücksichtigung der Arbeiterjungenbewegung, Archiv der deutschen Jugendbewegung, Jahrbuch, 15, 1984/1985, 201-252, Burg Ludwigstein.

${ }^{19}$ Veja LOGAN, Thomas Harvey 1972: "The invention of Zoning in the Emerging Planning of Late nineteenth-century Germany, Ph. D. dissertation, University of North Carolina em Chapel Hill.

${ }^{20}$ Veja p. ex. VERDONK, O., MATHÉ, A., RELF, P.D., MATSUO, E., GRÖNING, G., e J.RAMMELOO (eds.) 2000: New and Specialized Crops and Products, Botanic Gardens, and Human-Horticulture Relationship, Part 13, Proceedings of the XXV International Horticultural Congress, Acta Horticulturae, 523, Leuven, Bélgica.
} 
FIGURA 14 - ESQUEMA DE PLANOS DE ESPAÇOS LIVRES, VISTA GERAL. OS TRÊS NÍVEIS DE PLANOS DE ESPAÇOS LIVRES: 1 - SISTEMA DE ESPAÇOS LIVRES; 2 - ESTRUTURA DOS ESPAÇOS LIVRES; 3 - INFRA-ESTRUTURA DOS ESPAÇOS LIVRES.

Univ. Prof. Dr. Gert Groening

Garden Culture and Open Space Development

Institute for History and Theory of Design

Berlin University of the Arts

Berlin, Germany

Scheme of Open Space Plans

\begin{tabular}{|c|c|c|c|c|c|c|}
\hline kind of plan & open space & infrastructure & space & structure & space & system \\
\hline name of plan & detail & blueprint & $\begin{array}{l}\text { quarter } \\
\text { plan }\end{array}$ & $\begin{array}{r}\text { specific } \\
\text { open space } \\
\text { plan }\end{array}$ & land use plan & perspective \\
\hline contents & $\begin{array}{l}\text { work plan } \\
\text { construction }\end{array}$ & $\begin{array}{r}\text { location } \\
\text { and } \\
\text { specification } \\
\text { of open space } \\
\text { elements }\end{array}$ & $\begin{array}{l}\text { open space } \\
\text { distribution } \\
\text { in a quarter }\end{array}$ & $\begin{array}{r}\text { specific } \\
\text { open } \\
\text { space } \\
\text { distribution }\end{array}$ & $\begin{array}{l}\text { not built-up } \\
\text { space in a } \\
\text { city }\end{array}$ & $\begin{array}{r}\text { not built-up } \\
\text { space in a } \\
\text { region }\end{array}$ \\
\hline purpose & $\begin{array}{l}\text { basics for } \\
\text { construction }\end{array}$ & design & $\begin{array}{l}\text { delimitation } \\
\text { of design } \\
\text { areas }\end{array}$ & $\begin{array}{l}\text { visualization } \\
\text { of areas with } \\
\text { deficiencies }\end{array}$ & $\begin{array}{l}\text { visualization } \\
\text { of disparities }\end{array}$ & $\begin{array}{r}\text { delimitation } \\
\text { of areas for } \\
\text { building } \\
\text { and for } \\
\text { not-building }\end{array}$ \\
\hline scale & $1: 1-1: 20$ & $1: 50-1: 500$ & $1: 500-1: 10000$ & $\begin{array}{r}1: 10000 \\
-1: 20000\end{array}$ & $\begin{array}{r}1: 20000 \\
-1: 50000\end{array}$ & $\begin{array}{r}1: 50000 \\
-1: 100000\end{array}$ \\
\hline examples & $\begin{array}{l}\text { detail for } \\
\text { planting } \\
\text { detail for } \\
\text { construction }\end{array}$ & $\begin{array}{r}\text { courtyard } \\
\text { urban plaza } \\
\text { camping site } \\
\text { house garden }\end{array}$ & $\begin{array}{l}\text { old and new } \\
\text { residential } \\
\text { quarters } \\
\text { commercial } \\
\text { and } \\
\text { industrial } \\
\text { area pro }\end{array}$ & $\begin{array}{r}\text { track and } \\
\text { field area } \\
\text { playground } \\
\text { Kleingarten } \\
\text { cemetery } \\
\text { nature } \\
\text { rotection area }\end{array}$ & $\begin{array}{l}\text { open space } \\
\text { plan of } \\
\text { a city } \\
\text { landscape } \\
\text { plan }\end{array}$ & $\begin{array}{r}\text { regional open } \\
\text { space system } \\
\text { greenbelt }\end{array}$ \\
\hline
\end{tabular}

FIGURA 15 - SISTEMA REGIONAL DE ESPAÇOS LIVRES, RUHR 1985. SISTEMA DE ESPACOS LIVRES REGIONAL PARA A ÁREA DO RUHR. SÃO APONTADOS ESPAÇOS LIVRES EM GERAL E ÁREAS RESIDENCIAIS BEM COMO ÁREAS COMERCIAIS E RECREACIONAIS. AS BASES PARA ESTE PLANO FORAM DESENVOLVIDAS NOS ANOS 1920 QUANDO A ALEMANHA DESFRUTAVA DE UMA CONSTITUIÇÃO DEMOCRÁTICA PELA PRIMEIRA VEZ EM SUA HISTÓRIA. ESTE PLANO INICIAL AINDA É SEGUIDO NO COMEÇO DO SÉCULO XXI. VOLTAREI A ISTO EM UM MINUTO [MAIS A FRENTE GRÖNING RELACIONARÁ ESTÁ FIGURA COM A FIGURA 19]. CLARAMENTE VISÍVEL É O INTERESSE EM MANTER LIVRES AMPLAS ÁREAS NUMA DIREÇÃO NORTE-SUL ENTRE VÁRIAS CIDADES QUE SE ESTENDEM DE LESTE A OESTE.

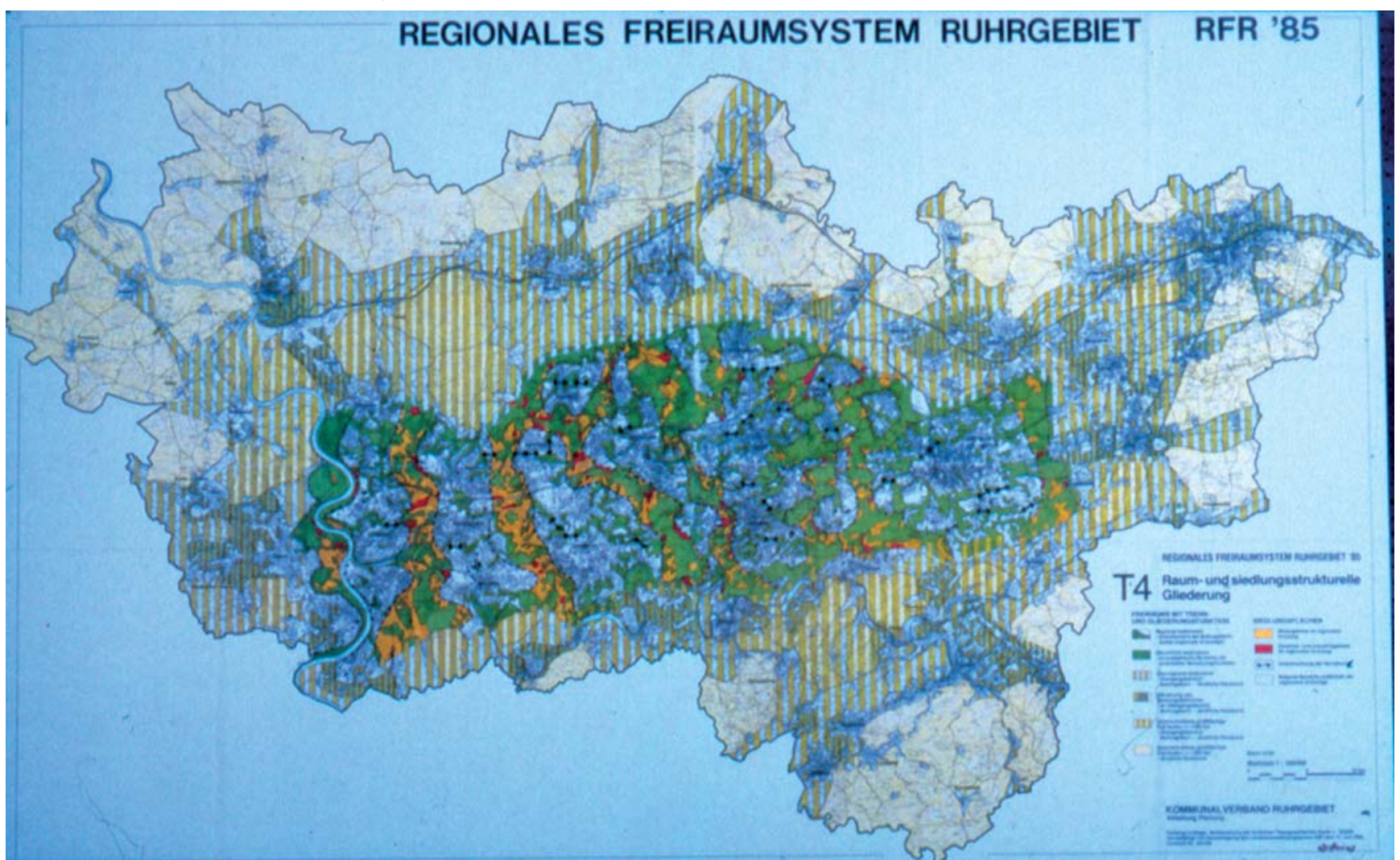

CONTRIBUIÇÃO: GERT GRÖNING 
FIGURA 16 - SISTEMA DE ESPAÇOS LIVRES DE ESSEN, 1927. AGORA POR VOLTA DE CEM ANOS ATRÁS, EM 1912, A PRIMEIRA SUGESTÃO FOI FEITA PARA GARANTIR O ESPAÇO LIVRE COMO PARTE DO DESENVOLVIMENTO URBANO EM ESSEN, UMA CIDADE IMPORTANTE NO DISTRITO DO RUHR. UM PLANO QUE SEGUE A IDÉIA DE PREVER ESPAÇOS LIVRES SUBMETIDA AO CRESCIMENTO DA CIDADE COMO FOI DESENVOLVIDO QUINZE ANOS DEPOIS EM 1927.

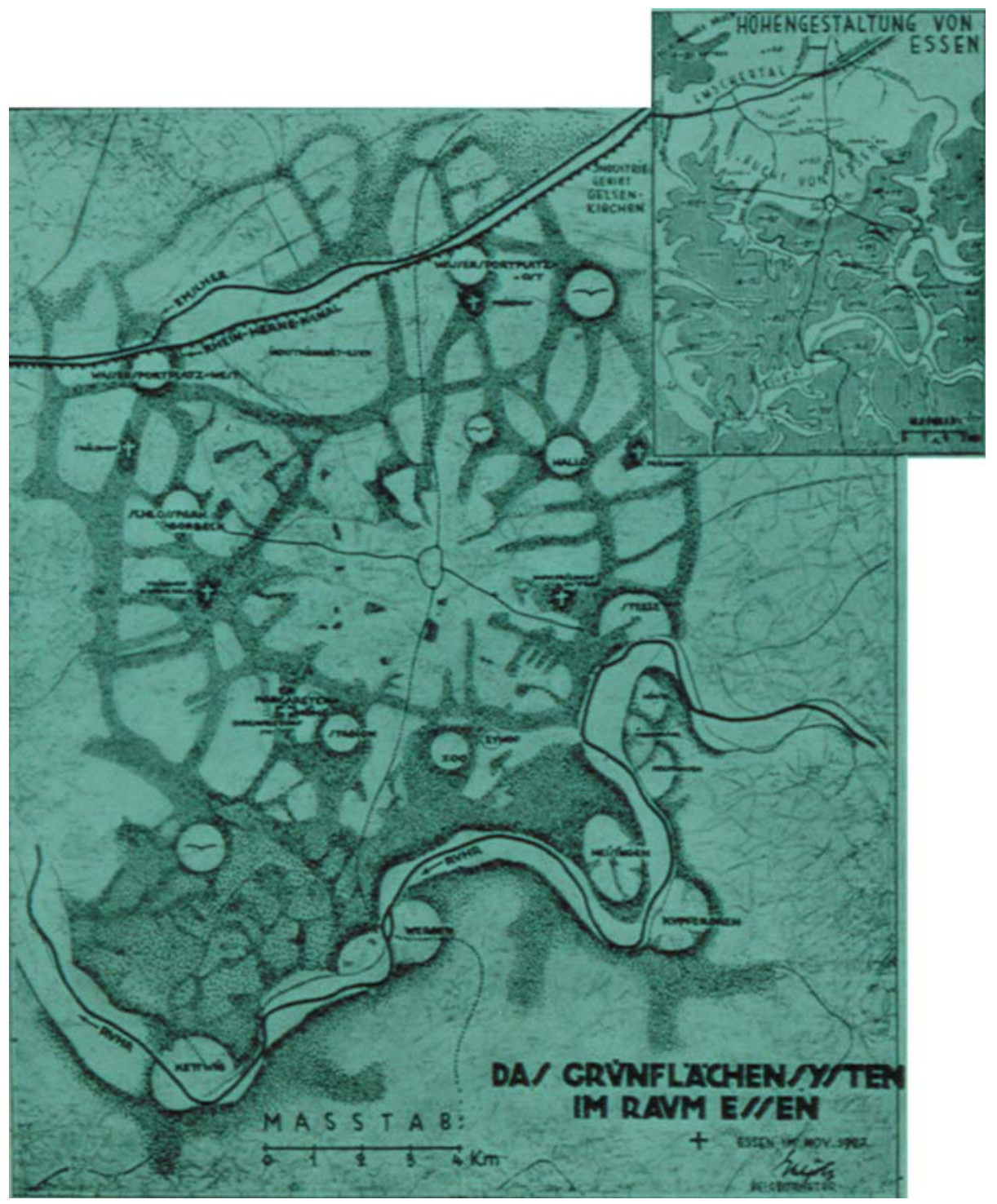

presentantes das iniciativas populares reúnem-se de modo a acompanhar o projeto ${ }^{21}$ (Figura 18).

Para Munique o arquiteto LAUX desenvolveu um "Sistema Aberto" no início do século XXI o qual de maneira exemplar constrói a idéia de um sistema de espaços livres. A rede de espaços livres no "Sistema Aberto" de LAUX não deve se restringir só a estruturas verdes. Toda- via inclui todas as categorias de espaços livres. Junto com estruturas de espaços livres de significado regional que alguns poderiam chamar "paisagem" e conexões verdes de ordem superior uma significativa estrutura completa o sistema. Onde se conhece como "Munique Norte" (Münchner Norden) abrange áreas de trilhas e esportes, agricultura, jardins e zonas verdes tais como as pla-

${ }^{21}$ Veja p. ex. VERDONCK, O., MATHÉ, A., RELF, P.D.,MATSUO, E., Gröning, G. e J. RAMMELOO (eds.) 2000: New and Specialized Crops and Products, Botanic Gardens, and Human-Horticulture Relationship, Part 13, Proceedings of the XXV International Horticultural Congress, Acta Horticulturae, 523, Leuven, Bélgica. 
FIGURA 17 - ARBORIZAÇÃO NO INTERIOR DE UMA ÁREA DE RENOVAÇÃO URBANA, HANNOVER, LINDEN SUL, QUADRA 44, TRABALHO ESTUDANTIL, BULTMANN, DITTUS, GRUNERT. PROPOSTA DE RENOVAÇÃO DE UMA ÁREA RESIDENCIAL URBANA INTERNA EM HANNOVER, BAIXA SAXÔNIA. O PLANO DE ESPAÇOS LIVRES PARA ESTA ÁREA MOSTRA CLARAMENTE AS FILAS DE ÁRVORES AO LONGO DAS RUAS E GRUPOS SEMICIRCULARES DE ÁRVORES AO LONGO DE UMA PROMENADE. ESTE É UM EXEMPLO DE ARBORIZAÇÃO DE UMA ÁREA DE RENOVAÇÃO URBANA.

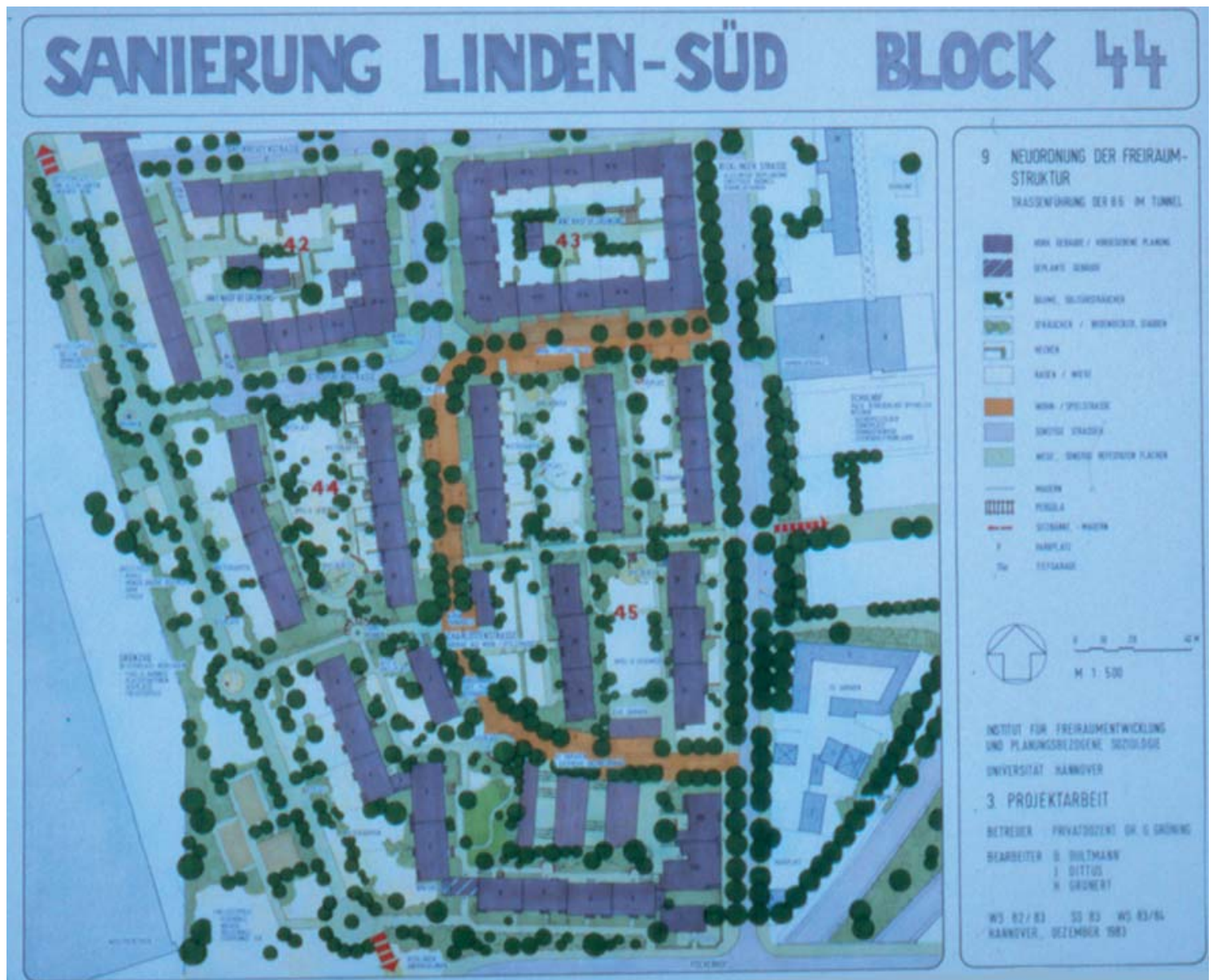

SUPERVISOR: GERT GROENING

nícies inundáveis do Isar e o Jardim Inglês, os trilhos do S-Bahn, o canal do Isar e a maioria das vias. Desta maneira o planejamento de espaços livres transforma-se num instrumento que permite checar o desenvolvimento de vários tipos de espaços livres. Funciona como parte de uma rede estrutural e um sistema de ordem estável que pode ser ampliado. A construção está subordinada a esse "sistema aberto". ${ }^{22}$

Um plano comparável de desenvolvimento de espaços livres, que poderia bem ser considerado seriamente para São Paulo, foi chamado de "Plano Diretor do Parque Paisagístico Emscher" (Masterplan Emscher Landschaftspark) 2010 (Figura 19). Este plano é mais parecido com uma estrutura para uma futura ação o qual serve como base para decisões locais dentro de um contexto regional. O objetivo desse plano de espaço livre é "gerenciamento inteligente" ("intelligente Steuerung") do desenvolvimento de uma área bem maior que, se tivéssemos uma chance enfim de comparar com alguma região da Alemanha, poderíamos comparar à área de São Paulo. Esse plano foi autorizado no verão de 2002 e, no momento, está na mesa para as dezessete cidades, os dois condados (Landkreise), os três distritos governamentais (Regierungsbezirken), a Associação de Emscher e de Lippe (Emschergenossenschaft/ Lippeverband), a Associação de comunidades da Área do Ruhr (Kommunalverband Ruhrgebiet), e o Estado da Renania do Norte-Westfália (Land Nordrhein-Westphalen) para ser

${ }^{22}$ LAUX, GUNTER 2002: Transformation: Open System, Garten + Landschaft, 112, 9, 23-25. 
FIGURA 18 - CONCEPCÃO VERDE E DE ESPACCOS LIVRES DE BREMEN, 1999. GREEN NET BREMEN (GRÜNES NETZ BREMEN), EXEMPLO DE UM SISTEMA DE ESPAÇOS LIVRES DO COMEÇO DO SÉC. XXI; LEGENDA DE CIMA PARA BAIXO: EM CIMA, SINAL DE CUNHA VERDE (GRÜNER KEIL); ZIG ZAG, ANEL VERDE INTERNO; LISTAS, ANEL VERDE EXTERNO; BLOCOS, CONEXÕES VERDES; RUBRICAS OU DIAMANTES (KARO), DIVISA DE PARQUE NATURAL; ÁREAS VERDE-AMARELAS, PREFERÊNCIA PARA RECREAÇÃO AO AR LIVRE; ÁREAS VERDES, PREFERÊNCIA PARA NATUREZA NÃO ANTRÓPICA; LINHA VERMELHA, CICLOVIA AO LONGO DA PERIFERIA URBANA.
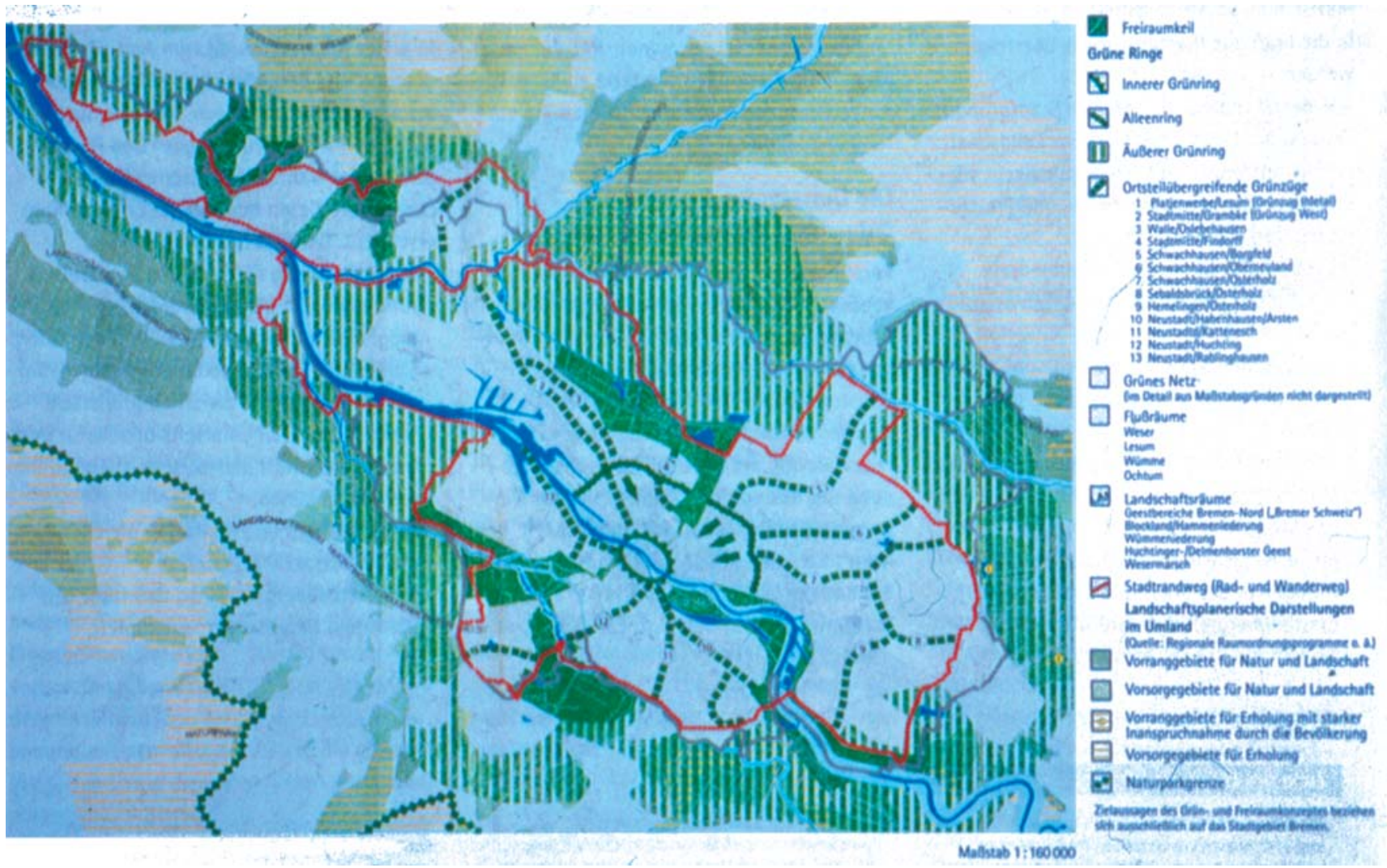

aprovada como resolução. Segue uma antiga tradição de planejamento de espaços livres nesta Região ${ }^{23}$ que foi estabelecida pela "Associação para urbanização da Área do Ruhr" (Ruhrsiedlungsverband), durante o primeiro período de democracia na Alemanha nos anos de 1920. Os objetivos desse plano de espaço livre são:

- alcançar consenso sobre centros de desenvolvimento dentro da região de Emscher;

- concordar com as dimensões do novo vale do Emscher como projeto principal;

- a integração da restrição do rio e a construção do parque;

- integração ativa da agricultura na construção do parque e na sua manutenção;
- continuidade e desenvolvimento de bem sucedidos centros, tais como cultura da indústria e natureza, novos parques, bem como limites territoriais e tipo de limite territorial;

- a apropriação da paisagem urbana e o desenvolvimento de novas maneiras de percepção via arte;

- o posterior desenvolvimento da infra-estrutura do parque e de informação sobre o parque;

- o cuidado e a manutenção do parque;

- as bases financeiras do parque;

- uma aceitação obrigatória entre todas as instituições participantes para o desenvolvimento do parque nos anos vindouros. ${ }^{24}$

${ }^{23}$ Veja GRÖNING, Gert 1998: Die Suche nach der "Landschaftsmitte", Kursbuch, 131, 55-69, Berlim; veja também WOLSCHKE, Joachim e Gert GRÖNING 1984: Regionalistische Freiraumgestaltung als Ausdruck autoritären Gesellschaftsverständnisses?, kritische Berichte, 12, 1, 5-47.

${ }^{24}$ Veja SCHEUVENS, Rudolf e Jens CÜPPERS 2004: Masterplan Emscher Landschaftspark, Steuerungsinstrument Masterplan, Garten und Landschaft, 114, 7,9-11. Veja também as outras contribuições nesse número da Garten und Landschaft que elaboram mais este conceito de plano de espaço livre por Auf mkolk e Moczala, Kasper e Terfrüchte, Rohler e Fritz, Lohrberg, Lorenz e Törkel. 
FIGURA 19 - PLANO DIRETOR EMSCHER PARK, 2004. LEMBRAM-SE DO SLIDE QUE MOSTREI-LHES ALGUNS MINUTOS ATRÁS? (FIGURA 15). ESTA É A MESMA CONCEPÇÃO DE ESPAÇO LIVRE PARA A ÁREA DO RUHR A QUAL É AGORA AJUSTADA PARA AS NECESSIDADES DO RUHR EM 2010. A FIGURA DE CIMA MOSTRA OS ESPAÇOS LIVRES REGIONAIS COMO ESTAVAM EM 2002, A FIGURA DO MEIO INDICA EM VERMELHO QUAIS OS NOVOS ESPACCOS LIVRES QUE FORAM ACRESCENTADOS DE 2002 A 2004 E A FIGURA DE BAIXO MOSTRA OS ESPAÇOS LIVRES REGIONAIS COMO ELES SÃO ATUALMENTE. CERCA DE 116 QUILÔMETROS QUADRADOS FORAM ACRESCENTADOS EM DOIS ANOS DE 2002 A 2004. EM 2010 OS PLANOS ESTARÃO EM OPERAÇÃO PARA DESENVOLVER ESSAS ÁREAS RECENTEMENTE ACRESCENTADAS DE ACORDO COM OS INTERESSES DAS CIDADES E CONDADOS
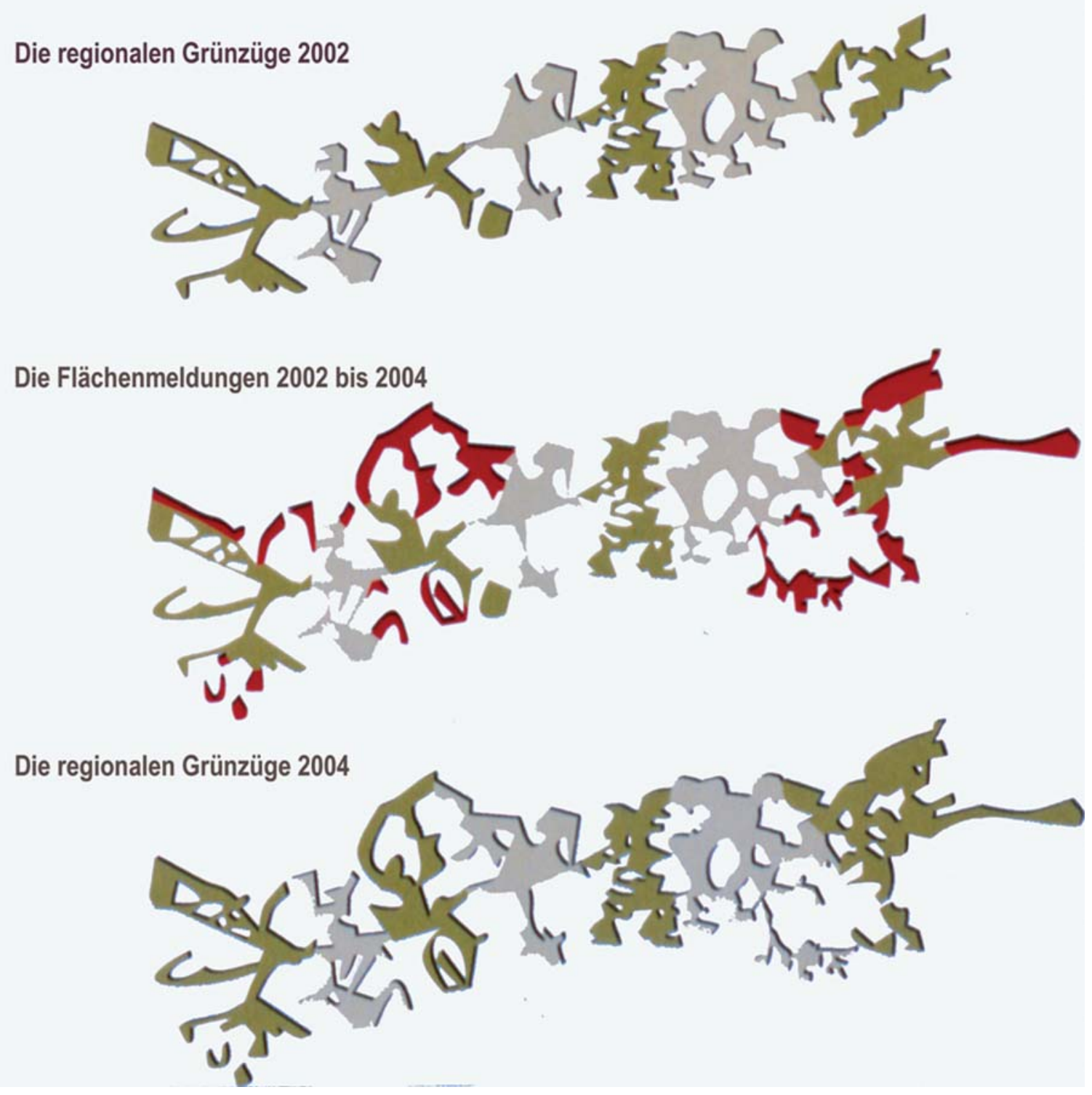

Nesses exemplos é evidente que promover e cuidar dessas idéias em instâncias privadas ou longe de instituições democráticas não conduz a nada. Um sem número de vezes é necessário informar o mais cedo e integralmente àqueles que supostamente aproveitarão de tal planejamento. Quando, por exemplo, a nova lei de proteção à natureza da República Federal da Alemanha exige criar "um sistema de rede de biótopos para dez por cento do território pelo menos" 25 e os proprietários da terra não sabem nada a respeito então, o conflito está programado. ${ }^{26}$

${ }^{25}$ Veja Bundesnaturschutzgesetz 2001, parágrafo 3-novo. 227,12-13.

${ }^{26}$ Veja, entre outros, uj. [Ulrich Jasper] 2000: Neues Naturschutzgesetz, neue Schranken, Unabhängige Bauernstimme, Oktober, Nr. 
Univ. Prof. Dr. Gert Groening

Garden Culture and Open Space Development

Institute for History and Theory of Design

Berlin University of the Arts

Berlin, Germany

Scheme of Open Space Plans

\begin{tabular}{|c|c|c|c|c|c|c|c|}
\hline kind of plan & open space & infrastructure & open & structure & space & system & \\
\hline name of plan & detail & blueprint & $\begin{array}{l}\text { quarter } \\
\text { plan }\end{array}$ & $\begin{array}{r}\text { specific } \\
\text { open space } \\
\text { plan }\end{array}$ & land use plan & perspective & \\
\hline contents & $\begin{array}{l}\text { work plan } \\
\text { construction }\end{array}$ & $\begin{array}{r}\text { location } \\
\text { and } \\
\text { specification } \\
\text { of open space } \\
\text { elements }\end{array}$ & $\begin{array}{l}\text { open space } \\
\text { distribution } \\
\text { in a quarter }\end{array}$ & $\begin{array}{r}\text { specific } \\
\text { open } \\
\text { space } \\
\text { distribution }\end{array}$ & $\begin{array}{l}\text { not built-up } \\
\text { space in a } \\
\text { city }\end{array}$ & $\begin{array}{r}\text { not built-up } \\
\text { space in a } \\
\text { region }\end{array}$ & \\
\hline purpose & $\begin{array}{l}\text { basics for } \\
\text { construction }\end{array}$ & design & $\begin{array}{l}\text { delimitation } \\
\text { of design } \\
\text { areas }\end{array}$ & $\begin{array}{l}\text { visualization } \\
\text { of areas with } \\
\text { deficiencies }\end{array}$ & $\begin{array}{l}\text { visualization } \\
\text { of disparities }\end{array}$ & $\begin{array}{r}\text { delimitation } \\
\text { of areas for } \\
\text { building } \\
\text { and for } \\
\text { not-building }\end{array}$ & \\
\hline scale & $1: 1-1: 20$ & $1: 50-1: 500$ & $1: 500-1: 10000$ & $\begin{array}{r}1: 10000 \\
-1: 20000\end{array}$ & $\begin{array}{r}1: 20000 \\
-1: 50000\end{array}$ & $\begin{array}{r}1: 50000 \\
-1: 100000\end{array}$ & \\
\hline examples & $\begin{array}{l}\text { detail for } \\
\text { planting } \\
\text { detail for } \\
\text { construction }\end{array}$ & $\begin{array}{r}\text { courtyard } \\
\text { urban plaza } \\
\text { camping site } \\
\text { house garden }\end{array}$ & $\begin{array}{l}\text { old and new } \\
\text { residential } \\
\text { quarters } \\
\text { commercial } \\
\text { and } \\
\text { industrial } \\
\text { area pr }\end{array}$ & $\begin{array}{r}\text { track and } \\
\text { field area } \\
\text { playground } \\
\text { Kleingarten } \\
\text { cemetery } \\
\text { nature } \\
\text { rotection area }\end{array}$ & $\begin{array}{l}\text { open space } \\
\text { plan of } \\
\text { a city } \\
\text { landscape } \\
\text { plan }\end{array}$ & $\begin{array}{r}\text { regional open } \\
\text { space system } \\
\text { greenbelt }\end{array}$ & 2001 \\
\hline
\end{tabular}

Um breve olhar para outros significativos assuntos em desenvolvimento de cultura de jardins e espaços abertos, tais como lazer, processos de construção de residências, distribuição desequilibrada de espaços livres, nativismo e plantas modificadas por engenharia genética.

Muito mais pontos parecem ser importantes para o futuro da cultura do jardim e do desenvolvimento de espaços livres como parte da civilização urbana. Eu queria citar apenas brevemente alguns deles neste capítulo de conclusão.

Embora valores sobre a quantidade de lazer foram quase populares nos anos 1960 e 1970 na Alemanha e alhures na Europa, está longe de ficar claro como futuras quantidades de lazer vão ser distribuídas. Assumir que o lazer vai crescer parece questionável em muitas instâncias. Concomitantemente com este debate, o uso dos espaços livres necessita, também, de reflexão. Cresceria ou decresceria ou seria uma variável mais estável?

Por fim, a respeito do interesse em ter um lugar junto à água e desfrutar música parece não ter mudado muito no último século na Alemanha e, creio também, no Brasil. Parece, então, que durante o século XX os interesses relacionados aos espaços livres aumentaram mais do que diminuíram.

Todavia, pode-se assumir que um número de atividades evidentemente em espaços livres tendem a se localizar em edificações. Este processo é conhecido como interiorização em ambientes fechados das atividades dos espaços livres. Isto está relacionado a atividades como futebol, escalada, natação, tênis. Pode ser relativo, também, a árvores.

O processo de interiorização em edificações está, também, relacionado aos palácios de cristal nos quais cultivamos algumas plantas e animais que não se adaptam ao clima local. E, finalmente, esse processo, também, afetou uma das maiores atividades humanas no início do século XXI, compras em shopping centers onde você pode também encontrar arborização.

Quando a usina nuclear de Chernobyl explodiu na primavera de 1986 não só a idéia de uso dos espaços livres para o propósito de recreação e saúde, porém, também, a idéia de cultivar alimentos ao ar livre foi severamente abalada em muitos países europeus, inclusive a Alemanha. Quando na primavera de 2000 a maior parte das usinas nucleares do mundo concordaram em interromper a produção de armas nucleares este foi o primeiro passo para banir essa tecnologia louca. Ainda há um longo caminho antes que um acordo final seja alcançado. De qualquer forma penso que isto se deveu aos interesses de muitas pessoas representados pelo movimento ambiental para gozar de recreação no ar livre não contaminado e aí cultivar frutas e legumes, o que reforçou este acordo.

Francamente, parece-me estranho ler em planos de espaços livres contemporâneos cada vez mais infor- 
FIGURA 20 - OLYMPIA PARK, MUNIQUE, 1987. PESSOAS DESFRUTANDO DOS ESPAÇOS AO AR LIVRE NO PARQUE DAS OLIMPÍADAS EM MUNIQUE, 1987.

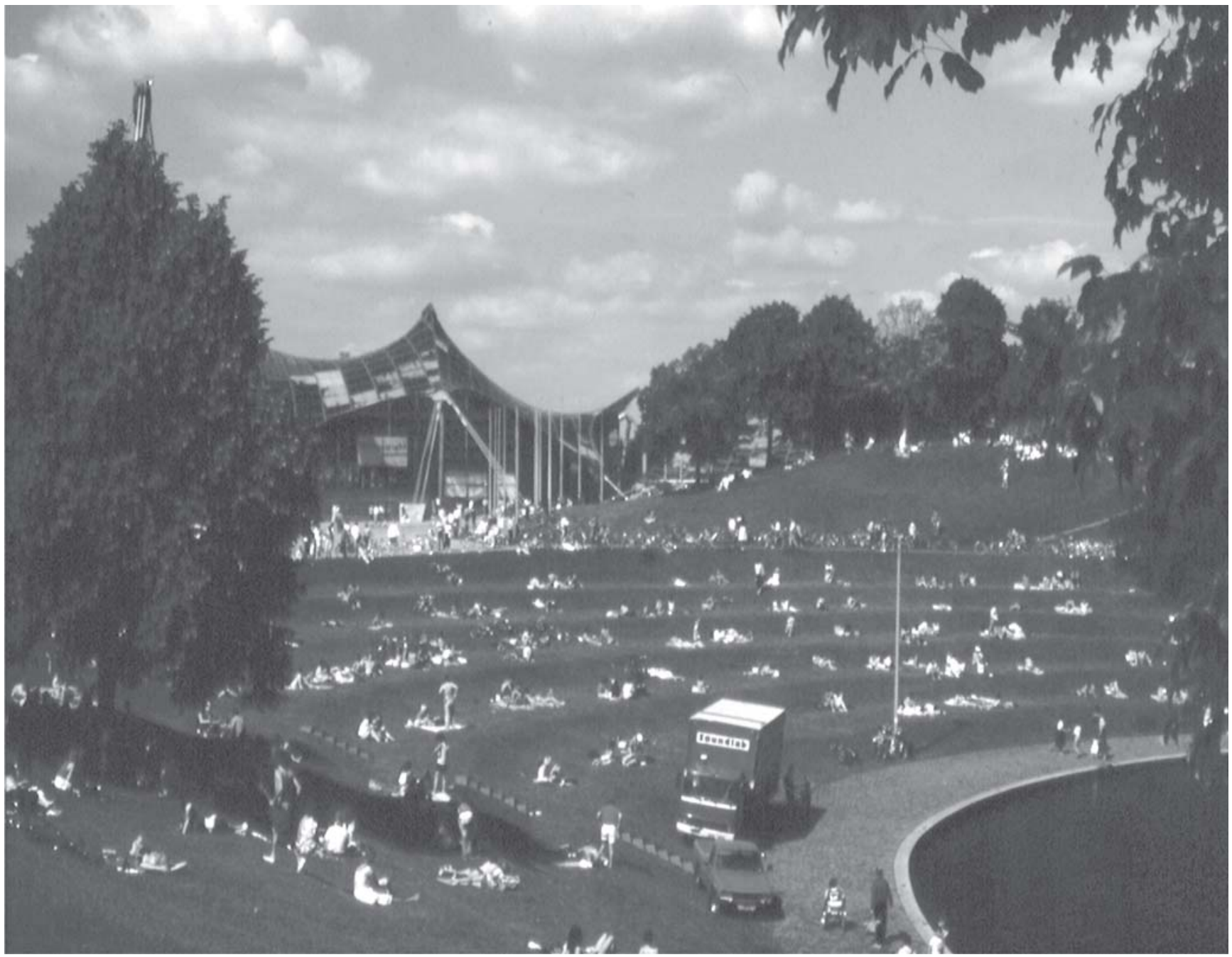

FOTO GERT GROENING

mações sobre a freqüência de borboletas e outros insetos bem como de certas espécies de plantas num determinado lugar do que a respeito da qualidade e quantidade de vários espaços livres nos quais as pessoas possam desfrutar numa cidade. Devemos falar tanto a respeito de insetos e plantas, porque abandonamos a esperança nos seres humanos? (Figuras 20 e 21)

Outras categorias de espaços livres tais como espaços livres em áreas residenciais parecem ter sido completamente negligenciadas. Ao mesmo tempo, a desigual distribuição de espaços livres é facilmente visível nas cidades. Isso não é lei natural, é feito pelo Homem.
Uma significativa tarefa do planejamento de espaços livres é chamar a atenção para essa desigual distribuição de espaços livres. ${ }^{27} \mathrm{~A}$ situação tornar-se-á pior, tornar-se-á estável ou será melhorada? O que isto significará para o uso e projeto dos espaços livres? Para mim, respostas a essas questões parecem-me mais relevantes que as onipresentes alusões a respeito de plantas e animais em perigo.

Se o que chamei de relação ambivalente entre seres humanos e natureza não antrópica é válido, então, ficará claro que a imensa maioria de nós não tem interesse em retornar a um modo existencial pré-industrial agrícola do

${ }^{27}$ Veja GROENING, Gert 2000: Zur Geschichte schichtspezifischer Freiraumversorgung, Harth, Annette, Scheller, Gitta und Wulf Tessin (ed.), Stadt und soziale Ungleichheit, 102-119, Opladen. 
FIGURA 21 - "AQUI FAMÍLIAS PODEM FAZER CAFÉ”, 1895. CAFÉ NUM PARQUE PÚBLICO, OUTRA VEZ UMA ATIVIDADE AO AR LIVRE BASTANTE AGRADÁVEL APRECIADA POR MUITOS HABITANTES URBANOS SE APRESENTAR UM BOM PADRÃO DE MANUTENÇÃO. AINDA MAIS SE ESTIVER ASSOCIADO A UM ACONTECIMENTO SOCIAL COMO, POR EXEMPLO, TOMAR UMA XÍCARA DE CAFÉ, UMA FEIRA DE LIVROS COMO TIVE A OPORTUNIDADE DE DESFRUTAR EM PORTO ALEGRE, ALGUNS ANOS ATRÁS, OUVINDO UM CONCERTO MUSICAL A CÉU ABERTO OU SE ESTIVER EQUIPADO COM EQUIPAMENTOS ESPECIAIS COMO TIVE A SORTE DE EXPERIMENTAR ALGUNS ANOS ATRÁS EM SÃO PAULO ONDE FILAS DE REDES PROVERAM UMA INSTALAÇÃO AGRADÁVEL PARA OS USUÁRIOS DE UM PARQUE PÚBLICO.

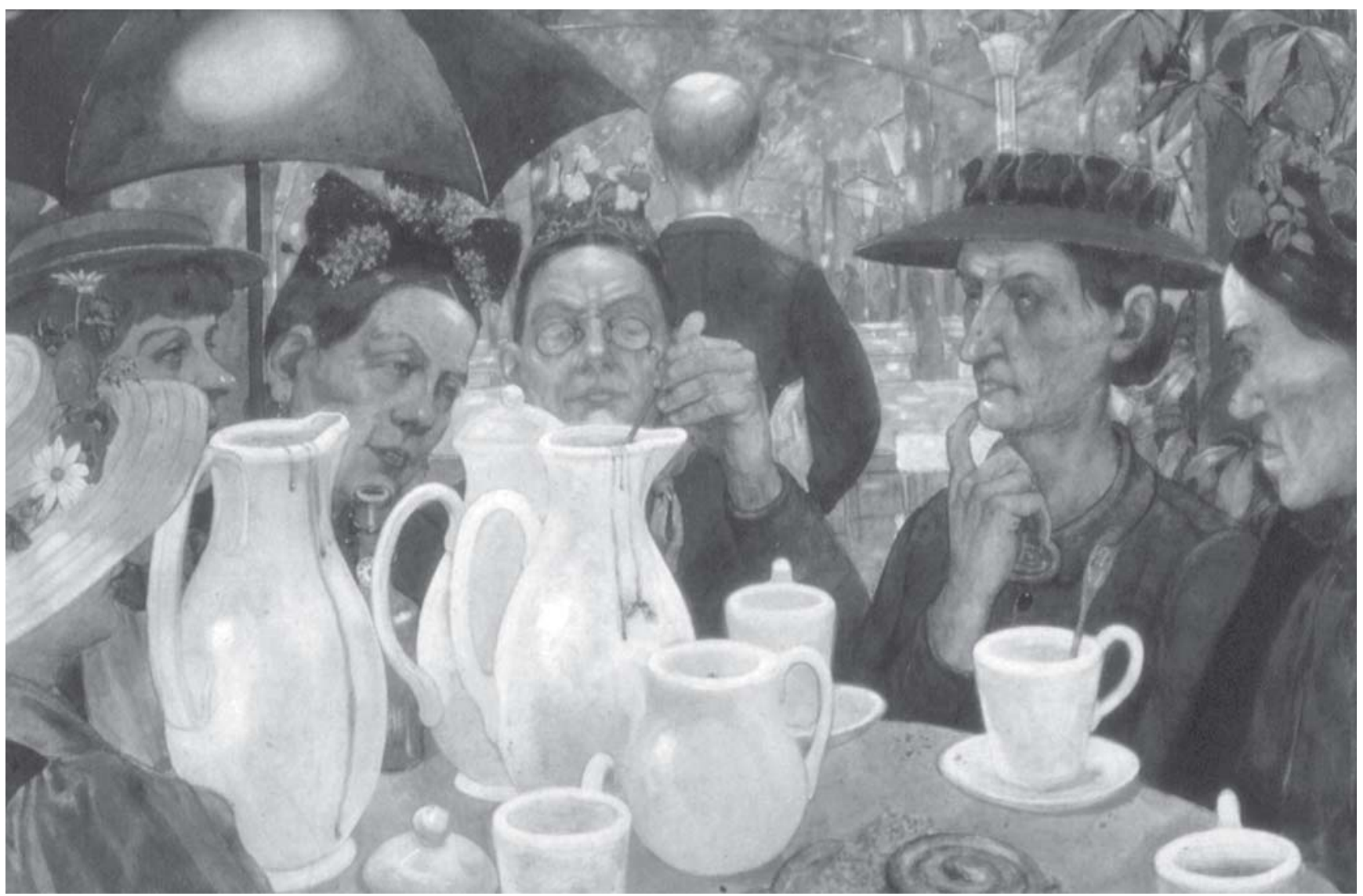

século XIX ou mesmo do século XVIII. A cultura do jardim e o planejamento de espaços livres têm uma visão mais próxima a esta apropriação indireta da natureza e seu impacto. Além disso, os objetivos os quais a cultura do jardim e do planejamento de espaços livres se sentem obrigados e como eles se relacionam com outros objetivos numa sociedade devem tornar-se um assunto se debate público.

Deve a quantidade de espaços livres numa cidade reduzir-se à mais baixa qualidade e menor quantidade? Deve a totalidade de uma cidade tornar-se uma área de proteção à natureza? Devem todos os espaços livres disponíveis serem destinados às atividades industriais e comerciais? Quem deve decidir sobre tais assuntos?

Planos, projetos e histórias de parques e jardins e outros espaços abertos devem considerar levar ao debate público esses valores que encorajam estar ao ar livre. Este é um vasto campo que só marginalmente foi trabalhado.

Enquanto que milhões são gastos só com o mapeamento de espécies de plantas e animais e não para pesquisa urgentemente necessária sobre as necessidades e interesses em constante mudança da população, os fundamentos dos planos de paisagem perdem a parte mais importante.

Por estranho que pareça, freqüentemente, os interesses relativos aos espaços livres conflitam-se uns 


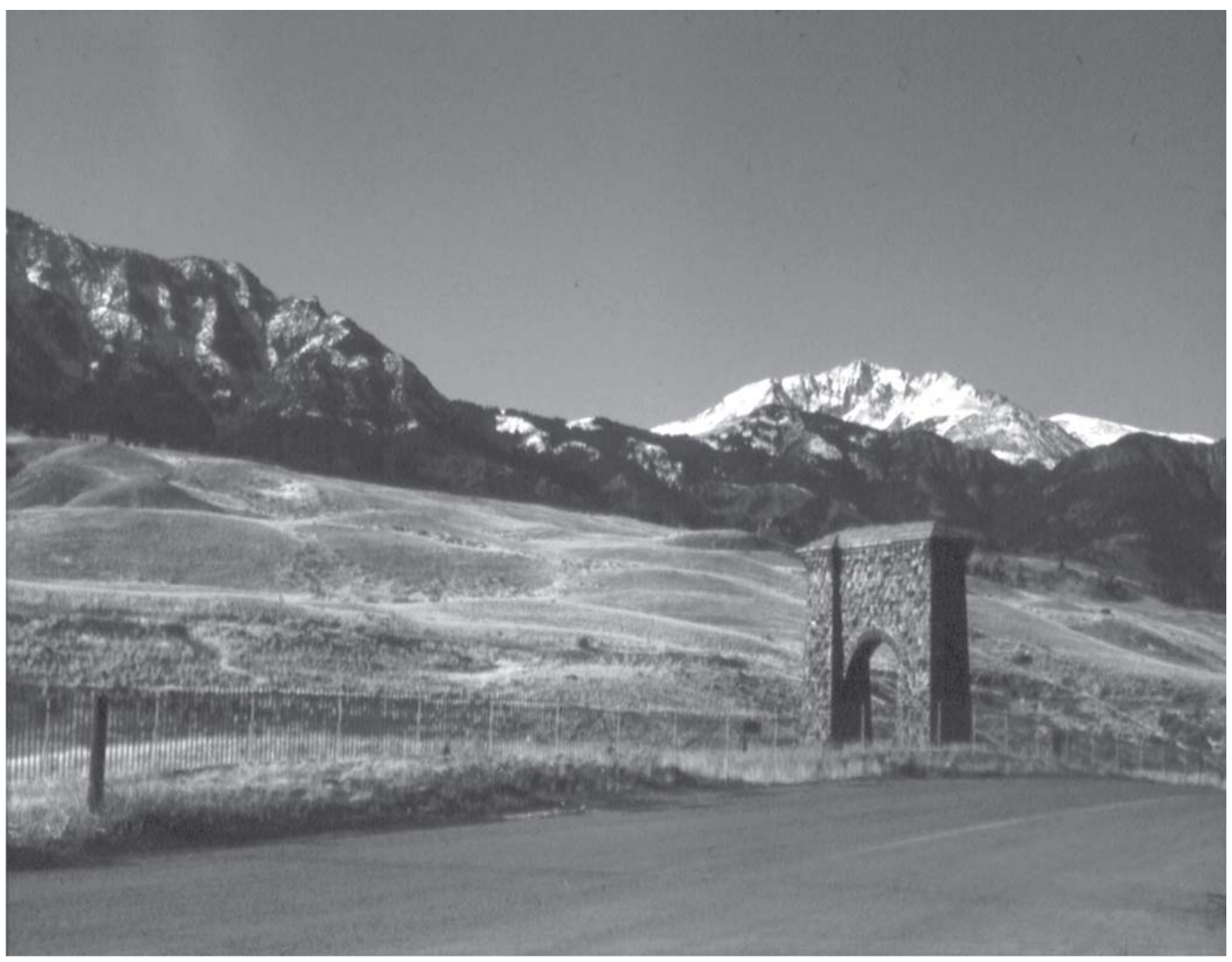

FOTO: GERT GRÖNING

com os outros. Um exemplo é a luta por mais fundos e publicidade em oposição a outros interesses.

Charles R. Jordan, o dinâmico diretor de parques e recreação de Portland, Oregon, não tem medo de falar de uma "guerra" que a American National Parks trava contra os parques nas cidades e grandes aglomerações. Jordan descobriu que nos Estados Unidos da América noventa por cento do dinheiro público é investido nos par- ques nacionais que são visitados por somente dez por cento da população. ${ }^{28}$ (Figura 22)

Outro exemplo é a luta entre aqueles que acreditam que o uso das assim chamadas espécies de plantas "nativas" deve ser obrigatório em oposição ao uso das assim chamadas plantas "não nativas". Essa luta não é nova. ${ }^{29}$

Mostrou-se muitas vezes na Alemanha durante os últimos cem anos mais ou menos. Especialmente nas p. 677.

${ }^{28}$ Veja GROENING, Gert 1999: Aspekte der Freiraumplanung im amerikanischen Nordwesten, Stadt und Grün, 48, 10, 674-679, aqui

${ }^{29}$ Veja GROENING, Gert e Joachim WOLSCHKE-BULMAHN 2004: The Native Plant Enthusiasm: Ecological panacea or xenophobia? Amoldia, 62, 4, 20-28; veja também GROENING, Gert e Joachim WOLSCHKE-BULMAHN 2003: The Native Plant Enthusiasm: ecological panacea or xenophobia? Landscape Research, 28, I, 75-88. Veja também THEODOROPOULOS, David I. 2003: Invasion Biology, Critique of a Pseudoscience, Blythe, California. 
FIGURA 23 - BOSQUE DE CARVALHOS, CARVALHOS COMO SÍMBOLO DA UNIDADE ALEMÃ, PINTURA DE GEORG FRIEDRICH KERSTING, 1815, GALERIA NACIONAL DE BERLIM. SOLDADOS LUTANDO PELA LIBERDADE NA ALEMANHA NUMA FLORESTA DE CARVALHOS, CARVALHOS SERVIRAM COMO SÍMBOLOS DE UNIDADE NACIONAL NO INÍCIO DO SÉCULO DEZENOVE E AINDA SÃO CONSIDERADOS BASTANTE ALEMÃES.

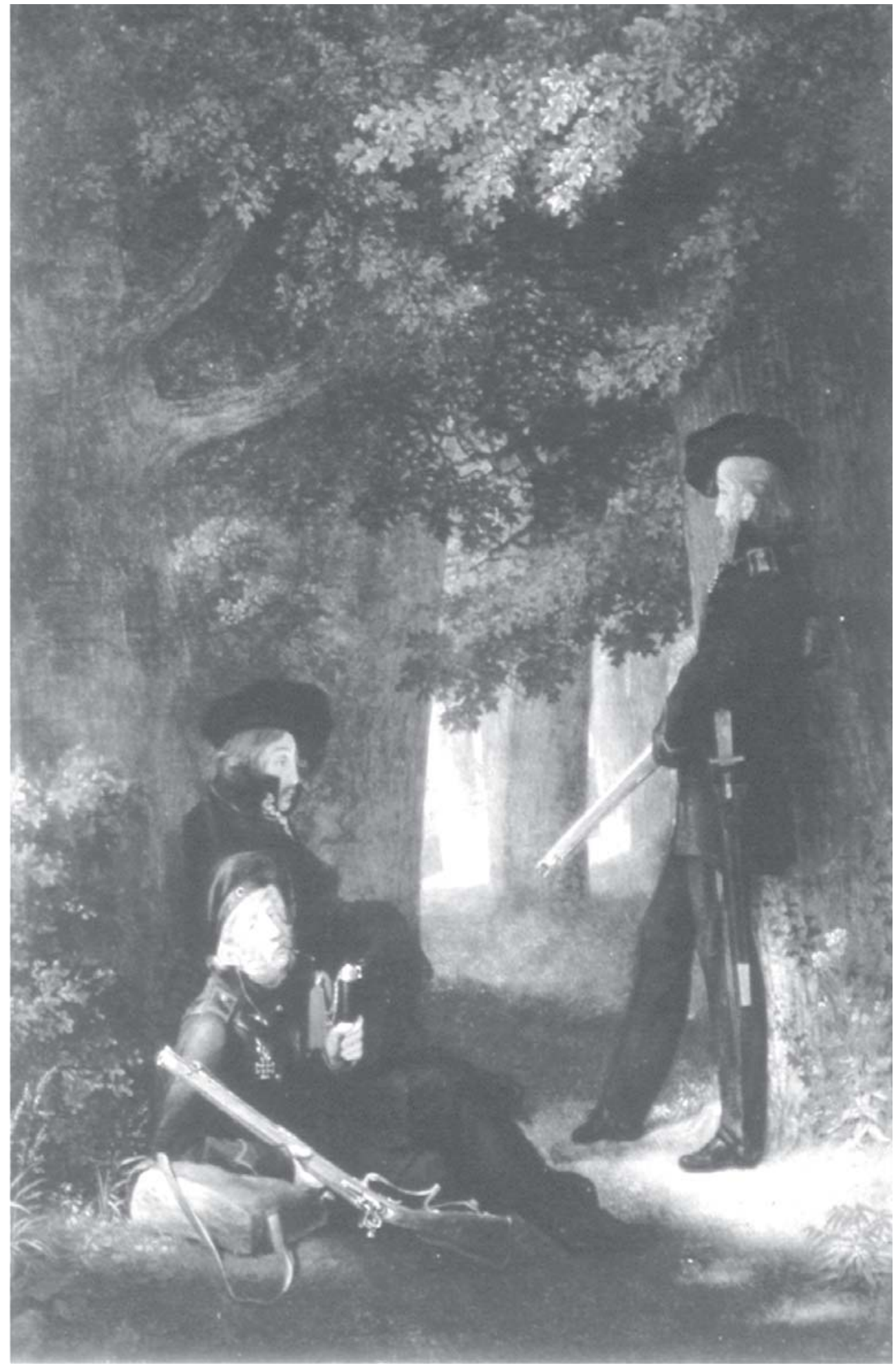


últimas duas décadas, a estupidez desse caso parece mais do que nunca atrativa. ${ }^{30}$

Numa grande escala, esta absurda distinção entre "nativo" e "não nativo" também fez caminho na literatura internacional. Siegfried Lenz, um famoso escritor alemão, levou essa questão de nativismo e as conseqüências dessa ecologia "nacional" em sua novela The Training Ground. ${ }^{31}$ No tempo da antiga República Federal da Alemanha, Zeller, proprietário de um viveiro de árvores no Schleswig-Holstein, que havia escapado da Prússia Leste depois da Segunda Guerra Mundial, queimou 100.000 jovens carvalhos em frente da Prefeitura da comunidade em que vivia como desacato a uma ordem ministerial. Ele havia cultivado as árvores com uma mistura de sementes alemãs e romenas. A razão desse comportamento é explicada como:

Uma instrução vinda do ministério. Eles elaboraram novas regras, desenterrando velhas regulamentações (...) foram as mais detestáveis regras imagináveis: eles determinaram que todas as árvores deveriam vir de sementes alemãs, de outra forma elas não poderiam ser vendidas. Um "pedigree", Bruno logo pensou disso: estes especialistas estão pedindo um "pedigree" de cada planta, isso foi o que eles elaboraram em seus escritórios; eles queriam só sementes alemãs semeadas em solo alemão. Tudo que nos falta agora é que eles estipulem bosta de vaca alemã como adubo. ${ }^{32}$

O personagem principal da novela de Lenz concluiu: "Nunca confie em alguém que pregue autenticidade e pureza ... Os apóstolos da pureza não nos trazem mais do que desgraça". ${ }^{33}$ (Figura 23)

A mais recente invenção de plantas geneticamente modificadas e a crescente produção industrial de plantas devem provocar reações similares.

Em muitos casos, penso que seria mais sábio para aqueles que ainda compartilham interesse em plantas, juntar forças ao invés de lutar em tais espetáculos secundários de nativismo.
Planejar e projetar espaços livres não é nada mais que uma forma de representação e isto necessita ser parte de um processo político numa democracia. Por outro lado, ecologistas, planejadores e designers não devem crer que eles são políticos porque eles entenderam que são parte de um processo político.

Especialmente como participante consciente dos processos políticos é que se deve ter clareza a respeito da complexidade que muitas vezes deve tornar difícil não se perder do caminho desejado. Todavia, isso não deve prejudicar a formulação de perguntas e procurar respostas que permitam alcançar os objetivos estabelecidos para o desenvolvimento da cultura dos jardins e dos espaços livres. Isto é basicamente diferente de esperar pelas questões dos políticos e respondê-las e, então, indicar os instrumentos pelos quais alcançar da melhor forma os objetivos dos políticos.

Sempre que ocorrem atividades de cultura do jardim e desenvolvimento de espaços livres, elas devem levar em conta a situação social e as condições econômicas e espaciais se quiserem ser bem sucedidas. Tais objetivos e reivindicações devem ser apresentados e discutidos num contexto de idéias em vigor sobre um estado social, iguais oportunidades para todos, justiça social, direitos sociais constitucionalmente assegurados para todos, livre escolha de crença, direito a educação, educação livre, atividade comercial livre e assim por diante. As condições sociais, econômicas, políticas e espaciais mudam e podem ser mudadas. Aqueles interessados na cultura dos jardins e desenvolvimento de espaços livres devem fazer sugestões.

Como se pode ver da rota do barco "Susanna" (Figura 24) foi necessária uma persistência extraordinária para, finalmente, dobrar o cabo Horn e bem que linhas similares pudessem aparecer se alguém quisesse traçar caminhos para alcançar um objetivo na cultura do jardim e do desenvolvimento de espaços livres como parte de processos de decisão democráticos em planejamento.

Muito obrigado pela sua paciência.

${ }^{30}$ Veja GROENING, Gert e Joachim, WOLSCHKE-BULMAHN 1992: Some Notes on the Mania for Native Plants in Germany, Landscape Journal, 11.2. 116-126, Landscape Journal, 11, 2, 116-126; veja também GROENING, Gert e Joachim WOLSCHKE-BULMAHN 1987: Die Liebe zur Landschaft, Teil III, Der Drang nach Osten, Zur Entwicklung der Landschaftspflege im Nationalsozialismus und während des Zweiten Weltkriegs in den "eingegliederten Ostgebieten", Arbeiten zur sozialwissenschaftlich orientierten Freiraumplanung, volume 9, Munique, especialmente capítulo "5.3 Fremdländische Pflanzen in der aussenstädtischen Landschaft und Bodenständigkeit als Planungsideal "O que segue serve de um recente exemplo. Em 1993 algumas árvores eram para ser cortadas em Berlim para a ampliação de um hospital. A autoridade competente achou que nem todas as árvores deveriam ser abatidas. Todavia após criteriosa inspeção descobriu-se que lá estavam um carvalho americano e um carvalho alemão. Assim que isso foi constatado a autoridade alemã deu permissão para derrubar o carvalho americano. O carvalho americano não era alemão e, assim, considerado de menor valor.

31 "Der Exerzierplatz" publicada em Hamburgo, Alemanha, em 1985; traduzida para o inglês em 1991 como "The Training Ground", New York, NY

32 LENZ, Siegfried 1991: The Training Ground, New York, NY, p.382.

${ }^{33}$ LENZ 1991, p. 392. 
FIGURA 24 - PASSAGEM DO BARCO "SUSANNA" PELO CABO HORN.

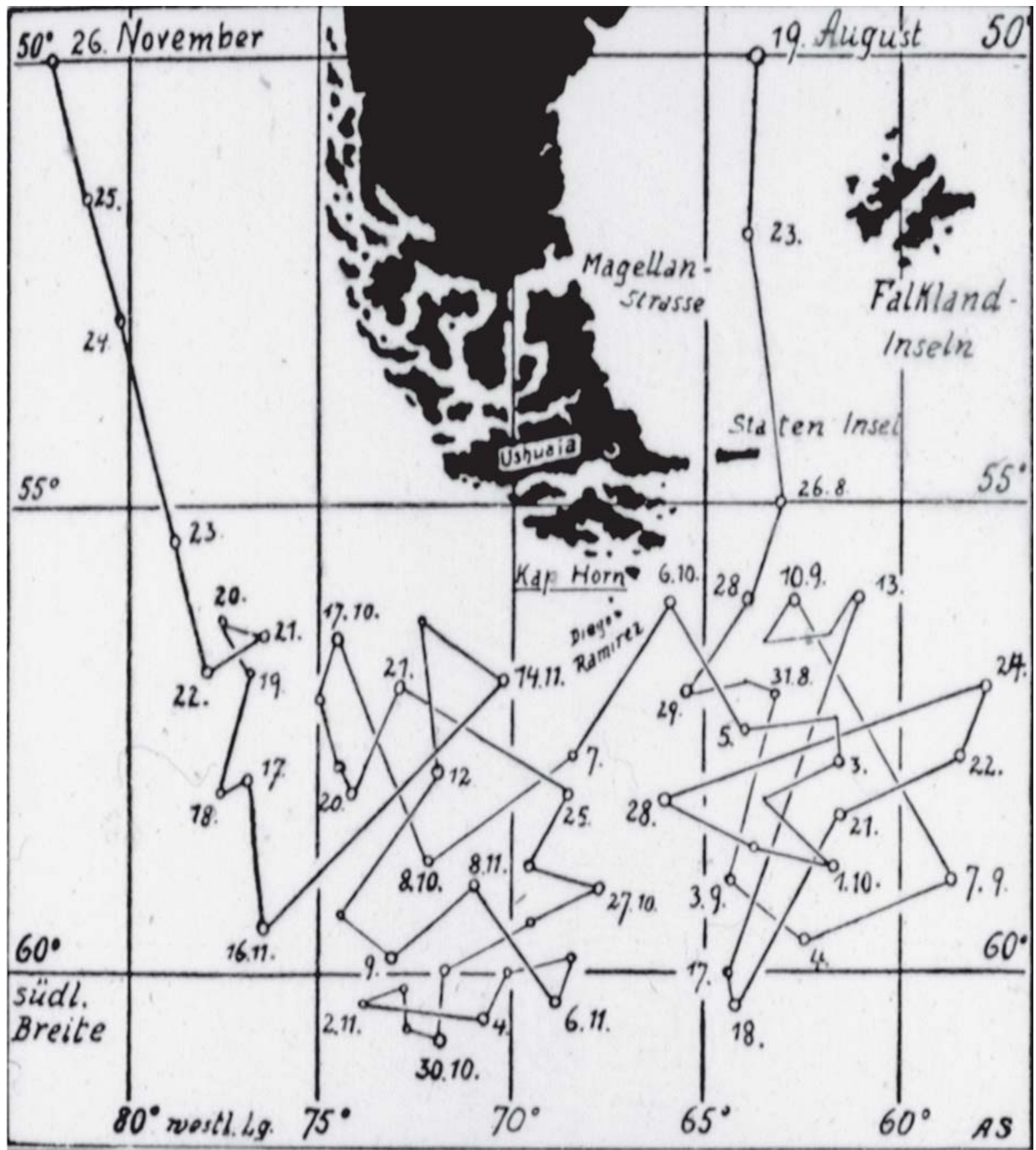

